\title{
Serotonergic Regulation of Excitability of Principal Cells of the Dorsal Cochlear Nucleus
}

\author{
Zheng-Quan Tang and $\odot$ Laurence 0 . Trussell \\ Oregon Hearing Research Center and Vollum Institute, Oregon Health and Science University, Portland, Oregon 97239
}

The dorsal cochlear nucleus (DCN) is one of the first stations within the central auditory pathway where the basic computations underlying sound localization are initiated and heightened activity in the DCN may underlie central tinnitus. The neurotransmitter serotonin (5-hydroxytryptamine; 5-HT), is associated with many distinct behavioral or cognitive states, and serotonergic fibers are concentrated in the DCN. However, it remains unclear what is the function of this dense input. Using a combination of in vitro electrophysiology and optogenetics in mouse brain slices, we found that 5-HT directly enhances the excitability of fusiform principal cells via activation of two distinct 5- $\mathrm{HT}$ receptor subfamilies, $5-\mathrm{HT}_{2 \mathrm{~A} / 2 \mathrm{C}} \mathrm{R}\left(5-\mathrm{HT}_{2 \mathrm{~A} / 2 \mathrm{C}}\right.$ receptor) and $5-\mathrm{HT}_{7} \mathrm{R}\left(5-\mathrm{HT}_{7}\right.$ receptor). This excitatory effect results from an augmentation of hyperpolarization-activated cyclic nucleotide-gated channels $\left(I_{\mathrm{h}}\right.$ or $\mathrm{HCN}$ channels). The serotonergic regulation of excitability is G-protein-dependent and involves cAMP and Src kinase signaling pathways. Moreover, optogenetic activation of serotonergic axon terminals increased excitability of fusiform cells. Our findings reveal that 5 -HT exerts a potent influence on fusiform cells by altering their intrinsic properties, which may enhance the sensitivity of the DCN to sensory input.

Key words: auditory; serotonin; tinnitus

\section{Introduction}

The serotonergic system modulates diverse physiological and behavioral functions, such as sleep, feeding, nociception, mood, and emotions (Lucki, 1998). Serotonergic dysfunction has been implicated in a variety of psychiatric disorders, including depression, anxiety, schizophrenia, Parkinson's disease, and Alzheimer disease (Meltzer et al., 1998; Jones and Blackburn, 2002; Huot et al., 2011). The majority of serotonergic neurons are found in the dorsal and medial raphe nuclei, sending widespread projections to many brain regions including the auditory system (Dahlström and Fuxe, 1964; Steinbusch, 1981; Descarries et al., 1982), with dense innervation in the cochlear nucleus (Steinbusch, 1981; Thompson and Thompson, 2001). Although the physiological function of 5-HT in the auditory system is unclear, it may differentially modulate the response to simple and complex sounds such as vocalizations (Ebert and Ostwald, 1992; Revelis et al., 1998; Hurley and Pollak, 1999, 2005; Hurley and Hall, 2011; Wood et al., 2013). Dysfunction of the serotonergic system is implicated in the generation or perception of tinnitus (Marriage

\footnotetext{
Received Nov. 18, 2014; revised Jan. 22, 2015; accepted Feb. 7, 2015.

Author contributions: Z.-Q.T. and L.T. designed research; Z.-Q.T. performed research; Z.-Q.T. analyzed data; Z.-Q.T. and L.T. wrote the paper.

This work was supported by NIH Grants NSO28901, DC004450 (L.O.T.), Hearing Health Foundation (Z.-Q.T.), and Tartar Trust Fellowship (Z.-Q.T.). We thank Drs Daniel Yaeger and Pierre F. Apostolides for preliminary observations that led us to investigate the serotonergic modulation in DCN; Dr Carolina Borges-Merjane for immunohistochemistry; Drs Hai Huang, Hsin-Wei Lu, Pierre F. Apostolides, and Daniel Yaeger for technical advice; Ruby Larisch and Michael Bateschell for help with mouse colony management and genotyping; all members of the Trussell lab for helpful discussions; and Dr John T. Williams for critical comments on the paper.

The authors declare no competing financial interests.

Correspondence should be addressed to Dr Laurence 0. Trussell, Oregon Health and Science University, 3181 Southwest Sam Jackson Park Road, L335A, Portland, OR 97239. E-mail: trussell@ohsu.edu.

DOI:10.1523/JNEUROSCI.4825-14.2015

Copyright $\odot 2015$ the authors $\quad 0270-6474 / 15 / 354540-12 \$ 15.00 / 0$
}

and Barnes, 1995; Simpson and Davies, 2000; Salvinelli et al., 2003; Caperton and Thompson, 2010). Moreover, it has been suggested that selective 5-HT reuptake inhibitors (SSRIs) often used in the treatment of depression and anxiety disorders (Stark et al., 1985; Wong et al., 1995), might be also used to treat tinnitus (Shemen, 1998; Folmer and Shi, 2004; Fornaro and Martino, 2010; Oishi et al., 2010; Baldo et al., 2012). Therefore, understanding the normal physiological effects of 5-HT in auditory system may provide insight into normal brain function and suggest new approaches in the treatment of tinnitus.

The role of 5-HT in auditory system may be of particular interest in the dorsal cochlear nucleus (DCN), where auditory and multisensory signals converge at fusiform principal cells. Among proposed functions of the DCN is sound source localization and orientation to sounds of interest (Sutherland et al., 1998; Imig et al., 2000; May, 2000; Oertel and Young, 2004), and is a proposed site of central tinnitus generation and modulation (Levine, 1999; Brozoski et al., 2002, 2012; Kaltenbach et al., 2004; Wang et al., 2009; Middleton et al., 2011; Dehmel et al., 2012; Koehler and Shore, 2013; Li et al., 2013; Luo et al., 2014). Moreover, the DCN receives a dense serotonergic innervation, originating predominantly from the dorsal and medial raphe nuclei (Parent et al., 1981; Steinbusch, 1981; Willard et al., 1984; Klepper and Herbert, 1991; Thompson et al., 1994, 1995; Hurley and Thompson, 2001; Thompson and Thompson, 2001), and contains multiple subtypes of 5-HT receptors, including $5-\mathrm{HT}_{1 \mathrm{~A}} \mathrm{R}$, 5- $\mathrm{HT}_{2 \mathrm{~A}} \mathrm{R}$, and 5- $\mathrm{HT}_{2 \mathrm{C}} \mathrm{R}$ (Pazos et al., 1985; Thompson et al., 1994; Wright et al., 1995; Cornea-Hébert et al., 1999; Thompson and Wiechmann, 2002), and measureable levels of 5-HT (Cransac et al., 1995). Yet, despite the potential physiological functions of serotonergic raphe-DCN pathway, it is unclear what 5-HT does in the DCN. Here, we found that 5-HT activates 
5- $\mathrm{HT}_{2 \mathrm{~A} / 2 \mathrm{C}} \mathrm{R}$ and $5-\mathrm{HT}_{7} \mathrm{R}$, and thereby exerts excitatory control of fusiform cells by altering their intrinsic properties; thus, 5-HT regulates the output of a primary auditory nucleus.

\section{Materials and Methods}

Slice preparation. All procedures were approved by the Oregon Health and Science University's IACUC. C57BL/6J wild-type mice of both sexes at P16-P49 were used for the majority of the experiments. For optogenetic experiments, the mice were B6; SJL-Tg (Tph2-COP4 ${ }^{\star} \mathrm{H} 13 \mathrm{R} /$ EYFP)5Gfng/J (Tph2-ChR2-YFP, JAX stock \#014555; Zhao et al., 2011). Mice were anesthetized by isoflurane inhalation and then decapitated. Brains were quickly removed and placed in a vibratome (Leica). Coronal slices containing the DCN (260-300 $\mu \mathrm{m})$ were prepared in an ice-cold cutting solution containing the following (in $\mathrm{mm}$ ): $87 \mathrm{NaCl}, 25 \mathrm{NaHCO}_{3}$, 25 glucose, 75 sucrose, $2.5 \mathrm{KCl}, 1.25 \mathrm{NaH}_{2} \mathrm{PO}_{4}, 0.5 \mathrm{CaCl}_{2}, 7 \mathrm{MgCl}_{2}$, and bubbled with $95 \% \mathrm{O}_{2} / 5 \% \mathrm{CO}_{2}$, and then the slices were maintained for $1 \mathrm{~h}$ in warm $\left(\sim 33^{\circ} \mathrm{C}\right)$ ACSF solution containing the following (in $\mathrm{mM}$ ): $130 \mathrm{NaCl}, 2.1 \mathrm{KCl}, 1.7 \mathrm{CaCl}_{2}, 1.0 \mathrm{MgSO}_{4}, 1.2 \mathrm{KH}_{2} \mathrm{PO}_{4}, 20 \mathrm{NaHCO}_{3}, 3$ $\mathrm{Na}$-HEPES, 11 glucose; bubbled with $95 \% \mathrm{O}_{2} / 5 \% \mathrm{CO}_{2}, 300-310 \mathrm{mOsm}$. After $1 \mathrm{~h}$ recovery, slices were maintained in the same solution at room temperature $\left(\sim 22^{\circ} \mathrm{C}\right)$ until recording.

Electrophysiology. Slices were transferred into a recording chamber, and continuously perfused with $\sim 33^{\circ} \mathrm{C} 95 \% \mathrm{O}_{2} / 5 \% \mathrm{CO}_{2}$ oxygenated ACSF at $\sim 2 \mathrm{ml} / \mathrm{min}$. The DCN neurons were visualized by Dodt contrast optics with a $60 \times$ water-immersion objective on the stage of an upright microscope (Olympus, BX51W). Fusiform and cartwheel cells were identified based on their location, morphology and electrophysiological properties (Manis et al., 1994; Zhang and Oertel, 1994; Golding and Oertel, 1997; Tzounopoulos et al., 2004). Synaptic transmission was blocked in most experiments by adding $10 \mu \mathrm{M}$ NBQX, $5 \mu \mathrm{M}$ R-CPP, $1 \mu \mathrm{M}$ strychnine, and $10 \mu \mathrm{M}$ SR95531. For whole-cell recordings, pipettes were filled with a solution containing the following (in $\mathrm{mm}$ ): $113 \mathrm{~K}$-gluconate, 9 HEPES, $2.75 \mathrm{MgCl}_{2}, 1.75 \mathrm{MgSO}_{4}, 0.1$ EGTA, $14 \mathrm{Tris}_{2}$-phosphocreatine, $4 \mathrm{Na}_{2}$-ATP, 0.3 Tris-GTP; osmolality adjusted to $\sim 290 \mathrm{mOsm}$ with sucrose, $\mathrm{pH}$ adjusted to 7.25 with $\mathrm{KOH}$. The membrane potential values are corrected for a $10 \mathrm{mV}$ junction potential. For loose cell-attached recordings, pipettes were filled with a normal ACSF solution. Patch pipettes (3-5 M $\Omega$ ) were pulled from borosilicate glass (WPI). For all voltageclamp experiments, series resistance $(<20 \mathrm{M} \Omega)$ was compensated by $65-80 \%$ and membrane potential was held constant at $-70 \mathrm{mV}$ except for experiments shown in Figure 4. Experiments were excluded if series resistance varied $>20 \%$ over the course of the recording. In currentclamp recordings, the pipette capacitance was canceled and bridge balance was maintained.

For microiontophoresis, methods were similar to a previous study (Perrier and Cotel, 2008): a micropipette (40-80 M $\Omega$ ) was filled with $50-100 \mathrm{~mm}$ serotonin hydrochloride dissolved in $165 \mathrm{~mm} \mathrm{NaCl}$, and the $\mathrm{pH}$ adjusted to 4.5 using $\mathrm{HCl}$. Retaining current of $-20 \mathrm{nA}$ were applied to micropipette to reduce drug leakage between ejection periods. 5-HT was ejected by applying positive currents $(+40-80 \mathrm{nA})$ for $3-5 \mathrm{~s}$. In control experiments, iontophoresis of drug carrier saline ( $165 \mathrm{~mm} \mathrm{NaCl}$ ) alone failed to evoke any detectable currents using the same iontophoresis current level as using those to eject 5-HT. The micropipette was positioned close to the soma of the recorded neurons.

Optogenetic stimulation was performed as previously described (Apostolides and Trussell, 2013). Briefly, wide-field activation of ChR2 was achieved with blue light from a LED $(470 \mathrm{~nm})$ transmitted through the fluorescent light path of the microscope. Photostimulation was delivered at $3 \mathrm{~min}$ intervals, and the maximal light intensity reaching the brain slice was $\sim 15 \mathrm{~mW} / \mathrm{mm}^{2}$.

Data acquisition and analysis. Data were collected using a Multiclamp 700B amplifier and pClamp 10 software (Molecular Devices). Signals were digitized at $10-50 \mathrm{kHz}$ with a Digidata $1322 \mathrm{~A}$ (Molecular Devices) and low-pass filtered at $1-10 \mathrm{kHz}$ for offline analysis.

To assess the effects of 5-HT on activation parameters of $I_{\mathrm{h}}$, an activation curve was obtained by fitting averaged normalized $I_{\mathrm{h}}$ currents with a Boltzmann equation of the form $I / I_{\max }=1 /\left[1+\exp \left(V_{\mathrm{m}}-V_{1 / 2}\right) / s\right]$ in which $I / I_{\max }$ is the normalized current, $V_{\mathrm{m}}$ is the membrane potential,
$V_{1 / 2}$ is the potential at half-maximal conductance and $s$ is the slope factor. The time constant of $I_{\mathrm{h}}$ activation was determined by fitting the currents evoked by a step to -80 or $-90 \mathrm{mV}$ potential with a double-exponential function of the form: $I_{\mathrm{t}}=I_{\mathrm{ss}}+I_{\text {fast }} \times \exp \left(-t / \tau_{\text {fast }}\right)+I_{\text {slow }} \times \exp \left(-t / \tau_{\text {slow }}\right)$, where $I_{\mathrm{t}}$ is the current amplitude at time $t, I_{\mathrm{ss}}$ is the steady-state current at a given potential, $I_{\text {fast }}$ and $I_{\text {slow }}$ denote the amplitude of the slow and fast current components, and $\tau_{\text {fast }}$ and $\tau_{\text {slow }}$ are the corresponding time constants for $I_{\mathrm{h}}$ activation.

All data are presented as mean \pm SEM unless specified otherwise, and statistical significance was assessed using Student's $t$ tests as appropriate; ${ }^{\star} p<0.05,{ }^{* *} p<0.01$ and ${ }^{* * *} p<0.001$.

Immunohistochemistry. Tph2-ChR2 transgenic mice (P20-P30) were deeply anesthetized with isoflurane and were transcardially perfused with warm $\left(\sim 38 \mathrm{C}^{\circ}\right) \mathrm{PBS}, \mathrm{pH} 7.4$, followed by ice-cold $4 \%$ paraformaldehyde (PFA) in PBS. After perfusion, mouse brains were dissected out and postfixed in $4 \%$ PFA overnight at $4^{\circ} \mathrm{C}$. The brains were rinsed thoroughly in PBS, pH 7.4, embedded in $4 \%$ agar, and sliced into $30 \mu \mathrm{m}$ coronal sections using a vibratome (Leica VT1000S). Next, sections were washed in PBS for 30 min and subsequently permeabilized in $1 \%$ Triton X-100 in PBS for $1 \mathrm{~h}$. After again being washed in PBS for $30 \mathrm{~min}$, sections were incubated for $30 \mathrm{~min}$ in blocking solution consisting $2 \%$ fish gelatin in PBS. The sections were then incubated with anti-GFP AlexaFluor 488conjugated antibody $(10 \mu \mathrm{g} / \mathrm{ml}$; Invitrogen) in blocking solution overnight at $4^{\circ} \mathrm{C}$. After being washed in PBS for $30 \mathrm{~min}$, sections were postfixed in 4\% PFA for $1 \mathrm{~h}$. After being washed again in PBS, sections were then mounted on slides and coverslipped with mounting medium. Images were acquired using laser-scanning confocal microscopy (Olympus FV1000).

Reagents. 5-HT was applied by either bath application or iontophoresis, and all other drugs were applied either in the bath or through the recording pipette. NBQX (2,3-dioxo-6-nitro-1,2,3,4-tetrahydrobenzo[f] quinoxaline-7-sulfonamide), R-CPP ((R)-3-(2-carboxypiperazin-4yl)propyl-1-phosphonic acid), SR95531 (Gabazine), and TTX (tetrodotoxin) were obtained from Abcam. 5-HT (serotonin hydrochloride), ketanserin, MDL-11939, SB-242084, $\alpha$-methyl-5-HT, SB-269970, WAY-100135, ZD7288, SQ22536, 8-Br-cAMP, PKC $_{19-31}$, genistein, PP1 (1-(1,1-dimethylethyl)-1-(4-methylphenyl)-1H-pyrazolo[3,4-d]pyrimidin-4-amine), and PP2 (3-(4-chlorophenyl) 1-(1,1-dimethylethyl)$1 \mathrm{H}$-pyrazolo[3,4-d]pyrimidin-4-amine) were purchased from Tocris Bioscience. All other drugs and chemicals were from Sigma-Aldrich.

\section{Results}

\section{5-HT regulates excitability of fusiform cells}

To explore the effects of 5-HT in DCN, whole-cell and loose cell-attached recordings were obtained from acute slices of mouse brainstem containing DCN. Under current-clamp, bath application of $10 \mu \mathrm{M} 5$-HT produced a significant depolarization of the resting membrane potential (control: $-68.1 \pm 1.5 \mathrm{mV}$, 5-HT: $-63.0 \pm 1.4 \mathrm{mV} ; p<0.001$, paired $t$ test, $n=8$ ). This depolarization led to enhancement of spontaneous spike activity (control: $0.2 \pm 0.1 \mathrm{~Hz}, 5-\mathrm{HT}: 3.9 \pm 1.1 \mathrm{~Hz} ; p<0.01, n=10$; Fig. $1 A, B$ ). These (and subsequent) experiments were performed in the presence of blockers of ionotropic glutamate receptors, $\mathrm{GABA}_{\mathrm{A}}$ receptors, and glycine receptors, except as otherwise noted, and thus the excitatory actions of 5- $\mathrm{HT}$ are likely to be postsynaptic in nature. Moreover, the depolarization produced by 5 -HT persisted in the presence of $1 \mu \mathrm{M}$ TTX or blockers of synaptic transmission, again indicating a postsynaptic mechanism of 5-HT on fusiform cells. The 5-HT-elicited increase in firing rate was reversed by returning the membrane potential to control levels with a negative bias current (data not shown), indicating that it was the 5-HT-induced depolarization that initiated spike firing, probably at a region at or close to the cell body. To examine the nature of 5-HT actions without any disturbance to the intracellular environment, loose cell-attached voltageclamp recordings were performed in fusiform cells. As with 
whole-cell recording, 5-HT (10 $\mu \mathrm{M})$ significantly increased the spike rate (baseline: $5.2 \pm 1.7 \mathrm{~Hz}, 5-\mathrm{HT}, 10.6 \pm 2.4 \mathrm{~Hz}$; $p<0.01, n=12$; Fig. $1 C, D)$. To examine how 5-HT affects the sensitivity of fusiform cells to current stimuli, a series of $1 \mathrm{~s}$ current steps were injected into fusiform cells, starting with $-30 \mathrm{pA}$ and incrementing by $20 \mathrm{pA}$, and spike rate at each current level was measured with and without 5-HT. These experiments showed that 5-HT shifted the input-output relation to the left in a dose-dependent manner (Fig. $1 E, F)$. To determine the specificity of this effect we also looked at the action of 5-HT on cartwheel interneurons, which provide potent inhibition to fusiform cells, and found that no detectable effects on spike rate or membrane potential (data not shown).

\section{5-HT-evoked response is mediated by 5- $\mathrm{HT}_{2 \mathrm{~A} / 2 \mathrm{C}} \mathrm{R}$ and $5-\mathrm{HT}_{7} \mathrm{R}$}

Consistent with the current-clamp data, fusiform cells voltage-clamped at holding potentials of $-70 \mathrm{mV}$ or close to the resting membrane potential, responded to bath application $(1,5$, or $10 \mu \mathrm{M})$ or iontophoresis $(50 \mathrm{~mm})$ of 5 - $\mathrm{HT}$ with a slow, steady, and reversible inward current (Fig. $2 A, B)$. The pharmacological identification of 5-HT receptor subtypes mediating the excitatory effects of 5-HT was investigated by using specific agonists and antagonists for 5-HT receptors in voltageclamped cells. Previous studies have shown that 5-HT can produce a slow depolarization of the resting membrane potential by activation of $5-\mathrm{HT}_{2} \mathrm{R}\left(5-\mathrm{HT}_{2}\right.$ receptor) in cortical neurons (Pierce and Peroutka, 1990; Araneda and Andrade, 1991; Tanaka and North, 1993; Zhang, 2003). Moreover, 5- $\mathrm{HT}_{2 \mathrm{~A}} \mathrm{R}$ and $5-\mathrm{HT}_{2 \mathrm{C}} \mathrm{R}$ are present in cochlear nucleus (Pazos et al., 1985; Thompson et al., 1994; Wright et al., 1995; Cornea-Hébert et al., 1999), We therefore asked whether these receptors mediate the 5-HT response in DCN. Application of the $5-\mathrm{HT}_{2 \mathrm{~A}} \mathrm{R}$ antagonist ketanserin at $10 \mu \mathrm{M}$ largely blocked the inward current elicited by bath application $(10 \mu \mathrm{M})$ or iontophoresis $(50 \mathrm{mM})$ of 5-HT (control: $-60.2 \pm 9.5$ pA, ketanserin: $-2.2 \pm 2.6 \mathrm{pA} ; p<0.001, n=9$; Fig. $2 A 1, A 2, C$ ), suggesting that the inward current may be mediated by $5-\mathrm{HT}_{2 \mathrm{~A}} \mathrm{R}$. However, $2 \mu \mathrm{M}$ ketanserin only partially blocked the response (data not shown), and a similar partial block was achieved with the selective 5- $\mathrm{HT}_{2 \mathrm{~A}} \mathrm{R}$ antagonist MDL-11939 $(2 \mu \mathrm{M} ; 45.3 \pm$ $8.6 \%$ of control, $p<0.05, n=11$; Fig. 2A3,C). Moreover, the $5-\mathrm{HT}_{2 \mathrm{C}} \mathrm{R}$ antagonist SB-242084 $(2 \mu \mathrm{M})$ slightly suppressed the 5-HT response ( $86.0 \pm 7.9 \%$ of control, $p<0.05 n=6$; Fig. $2 C$ ). Additionally, application of $25 \mu \mathrm{M} \alpha$-methyl-5-HT, a selective agonist of $5-\mathrm{HT}_{2} \mathrm{R}$, induced an inward current $(-37.0 \pm 6.8 \mathrm{pA}$; $n=4$; Fig. $2 B$ ) similar to that of $5-\mathrm{HT}$. These data suggest that a combination of $5-\mathrm{HT}_{2 \mathrm{~A} / 2 \mathrm{C}} \mathrm{Rs}$ contribute to the 5-HT-evoked response.

However, the inward current was not fully blocked by the 5- $\mathrm{HT}_{2 \mathrm{~A}} \mathrm{R}$ antagonist MDL-11939 plus $5-\mathrm{HT}_{2 \mathrm{C}} \mathrm{R}$ antagonist SB242084 (31.5 $\pm 13.9 \%$ of control, $p<0.05, n=3$ ). Previous studies have shown that ketanserin also exhibits affinity for 5- $\mathrm{HT}_{7} \mathrm{R}$ (5- $\mathrm{HT}_{7}$ receptor) (Shen et al., 1993; Jasper et al., 1997; Adham et al., 1998). Because ketanserin at high concentration (10 $\mu \mathrm{M})$ could almost completely block the 5-HT-evoked response, we wondered whether ketanserin was also blocking $5-\mathrm{HT}_{7} \mathrm{R}$ response to 5-HT. Indeed, it is well established that activation of $5-\mathrm{HT}_{7} \mathrm{R}$ can mediate a depolarizing effect on some central neurons (Cardenas et al., 1999; Chapin and Andrade, 2001a, b; Béique et al., 2004). Therefore, we examined the effects of SB269970 , a potent and selective antagonist for $5-\mathrm{HT}_{7} \mathrm{R}$, on the 5-HT-evoked current. We found that SB-269970 ( $1 \mu \mathrm{M})$ partially suppressed the 5 -HT-evoked current $(43.9 \pm 11.3 \%$ of control; $p<0.01, n=6$; Fig. 2A4,C). In addition, coapplication of SB269970 and MDL-11939 completely blocked the 5-HT current ( $2.0 \pm 9.4 \%$ of control; $p<0.01, n=4$; Fig. $2 C$ ). These data suggest that the 5-HT response results from the coactivation of $5-\mathrm{HT}_{2 \mathrm{~A} / 2 \mathrm{C}} \mathrm{R}$ and $5-\mathrm{HT}_{7} \mathrm{R}$. Immunochemical studies have shown that $5-\mathrm{HT}_{1 \mathrm{~A}} \mathrm{R}$ is also expresses in the cochlear nucleus (Pazos et al., 1985; Wright et al., 1995; Thompson and Wiechmann, 2002), although it is unclear in what cell types. However, WAY-100135 $(10 \mu \mathrm{M})$, a selective antagonist for $5-\mathrm{HT}_{1 \mathrm{~A}} \mathrm{R}$, did not affect the 5-HT current (100.6 $\pm 15.1 \%$ of the control; $p>0.05, n=3)$, suggesting that $5-\mathrm{HT}_{1 \mathrm{~A}} \mathrm{R}$ are not involved in the effects of $5-\mathrm{HT}$ on fusiform cells. Overall, these results indicate that activation of both $5-\mathrm{HT}_{2 \mathrm{~A} / 2 \mathrm{C}} \mathrm{R}$ and $5-\mathrm{HT}_{7} \mathrm{R}$ result in excitation of fusiform cells. 

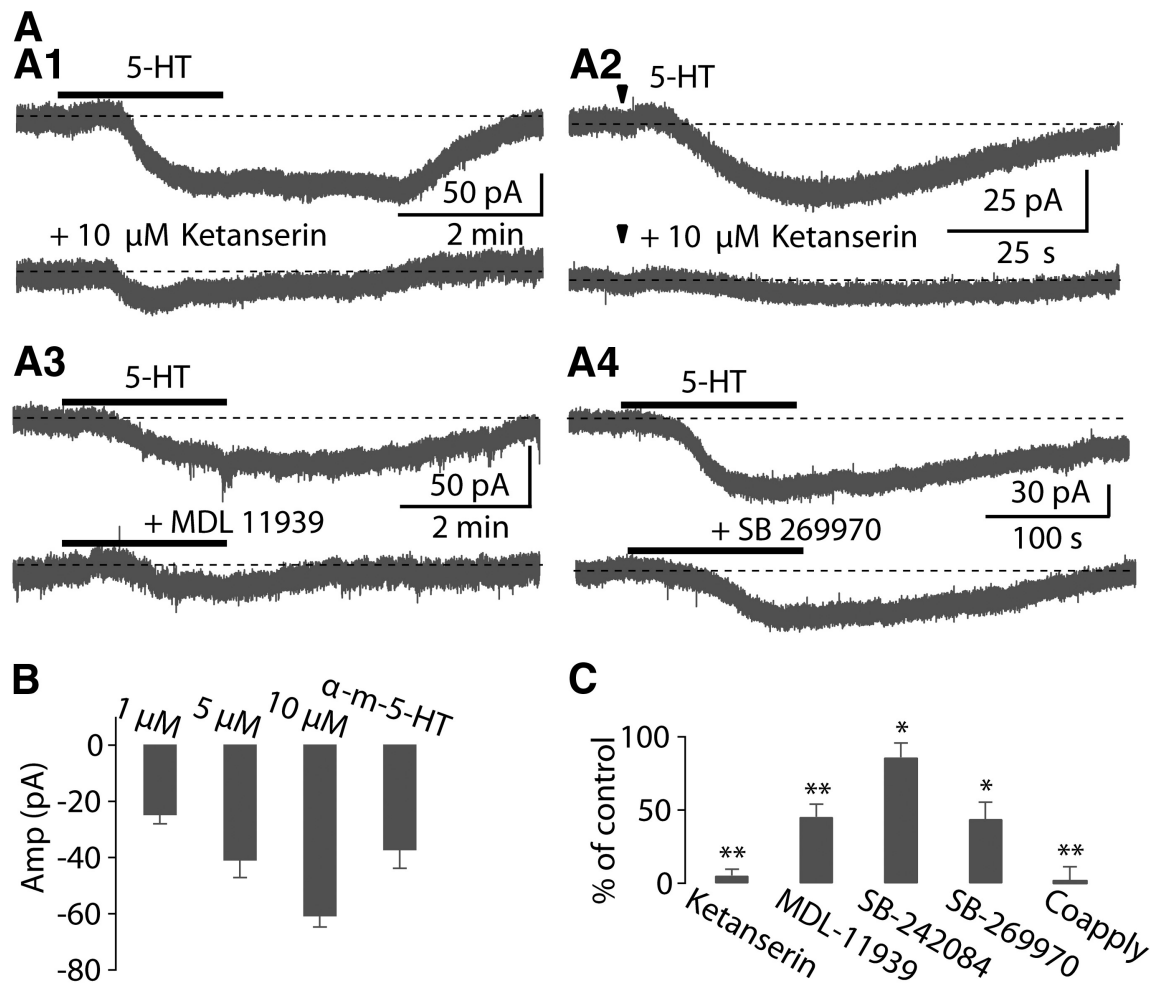

Figure 2. $5-\mathrm{HT}_{2 \mathrm{~A} / 2 \mathrm{C}} \mathrm{R}$ and $5-\mathrm{HT}_{7} \mathrm{R}$ are largely responsible for the inward current produced by $5-\mathrm{HT}$. $\boldsymbol{A}$, Under voltage-clamp, representative traces of slow inward currents elicited by bath application of $10 \mu \mathrm{m}$ or iontophoresis of $50 \mathrm{~mm} 5$-HT were almost completely abolished by $10 \mu \mathrm{m}$ ketanserin (A1, A2), partially blocked by $2 \mu \mathrm{M}$ MDL-11939 (A3), or $1 \mu \mathrm{m}$ SB-269970 (A4). Iontophoresis of 5-HT indicated by arrowhead. In this figure and following figures, gray dashed lines denote basal holding currents or the resting membrane potential before application of 5 -HT. $\boldsymbol{B}$, Summary of currents evoked by 5 -HT $(1 \mu \mathrm{M}, n=7 ; 5 \mu \mathrm{M}, n=$ 7; $10 \mu \mathrm{M}, n=35)$, and $\alpha$-methyl-5-HT $(25 \mu \mathrm{M}, n=4)$. C, Summary of effects of ketanserin $(n=9), \mathrm{MDL}-11939(n=11)$, SB-242084 $(n=6)$, SB-269970 $(n=6)$, and coapplication of SB-269970 plus MDL-11939 $(n=4)$ on the 5-HT-induced current. Error bars are \pm SEM.

\section{HCN channels are the downstream targets of serotonergic signaling}

Fusiform cells express a wide array of ion channels, including $\mathrm{Na}^{+}, \mathrm{Ca}^{2+}, \mathrm{K}_{\mathrm{ir}}, \mathrm{K}_{\mathrm{A}}, \mathrm{KCNQ}$, and $\mathrm{HCN}$ channels, the latter being the channel subtype that generates the $I_{\mathrm{h}}$ current (Hirsch and Oertel, 1988; Harasztosi et al., 1999; Kanold and Manis, 1999; Molitor and Manis, 2003; Pál et al., 2003; Leao et al., 2012). To determine what ion channels are responsible for the 5-HT response, the effects of blockers of $\mathrm{Na}^{+}, \mathrm{Ca}^{2+}, \mathrm{K}^{+}$, and $\mathrm{HCN}$ channels were tested on the 5-HT-induced current. Of these blockers, TTX, $\mathrm{Cd}^{2+}, \mathrm{Ba}^{2+}$, and XE991 failed to reduce the 5-HT-induced current (data not shown). However, $\mathrm{Cs}^{+}$and ZD7288, selective blockers of HCN channels, completely inhibited the 5-HT response (Fig. 3). Moreover, bath application of either $2 \mathrm{mM} \mathrm{Cs}^{+}$or $10 \mu \mathrm{M}$ ZD7288 alone induced an outward shift of holding current under voltage-clamp (Fig. $3 A, B$ ). Because 5-HTR (5-HT receptor) antagonists by themselves had no effect on holding current, this result indicates that HCN channels are active partially at rest, and indeed contribute to the resting membrane potential and regulate the excitability of fusiform cells, consistent with the previous studies (Pál et al., 2003; Apostolides and Trussell, 2014). We further compared the inward current evoked by 5-HT before and after application of $2 \mathrm{mM} \mathrm{Cs}^{+}$or $10 \mu \mathrm{M}$ ZD7288. The inward current evoked by 5 -HT was completely blocked by $\mathrm{Cs}^{+}$(control: $-68.8 \pm 19.5 \mathrm{pA}, \mathrm{Cs}^{+}:-5.7 \pm 2.3 \mathrm{pA} ; p<0.05, n=5$; Fig. $\left.3 C, D\right)$ or ZD7288 (control: $-64.3 \pm 8.0 \mathrm{pA}, 10 \mathrm{~min}$ after applying ZD7288: $-2.2 \pm 3.0 \mathrm{pA} ; p<0.001, n=7)$. Similarly, under current-clamp conditions, bath application of either $\mathrm{Cs}^{+}$or
ZD7288 alone caused a hyperpolarization of the membrane potential, and blocked spontaneous spiking firing, and also abolished the effects of 5-HT on the membrane potential or spike activity (Fig. $3 E, F)$. These data indicate that $\mathrm{HCN}$ channels are the primary downstream targets for these observed excitatory actions of 5-HT on fusiform cells.

We next explored how 5-HT affected the biophysical properties of $I_{\mathrm{h}}$ by measuring the voltage dependence of $I_{\mathrm{h}}$ from the amplitude of tail current relaxations. The experiments were performed in ACSF that contains $1 \mu \mathrm{M}$ TTX and $200 \mu \mathrm{M} \mathrm{Ba}^{2+}$, to block $\mathrm{Na}^{+}$channels and inward rectifier $\mathrm{K}^{+}$channels. Activation curves for $I_{\mathrm{h}}$ were constructed by applying a series of voltage steps from a holding potential at $-60 \mathrm{mV}$ to various levels to activate $I_{\mathrm{h}}$, and then activation voltage steps were followed by a test pulse to $-75 \mathrm{mV}$ with minimal contamination of the tail currents. The amplitude of tail current is proportional to the level of $I_{\mathrm{h}}$ conductance for a given prepulse voltage step. Activation curves for $I_{\mathrm{h}}$ were obtained by plotting tail current amplitudes against initial step potential, and then fitting with a Boltzmann function (see Materials and Methods). Application of $10 \mu \mathrm{M} 5$-HT resulted in a $5.6 \mathrm{mV}$ positive shift of the activation curve of $I_{\mathrm{h}}$ on the voltage axis (control: $-93.9 \pm 2.2 \mathrm{mV}, 5-\mathrm{HT}:-88.3 \pm 1.8 \mathrm{mV}$; $p<0.05$, $t$ test, $n=7$; Fig. $4 A-C$ ) without significantly affecting the amplitude of maximal tail current (control: $-418.1 \pm 84.7 \mathrm{pA}, 5-\mathrm{HT}:-439.8 \pm 96.6 ; p>0.05, n=$ $7)$, suggesting that the enhancement of $I_{\mathrm{h}}$ resulted from a shift in the activation properties of the $I_{\mathrm{h}}$, but not from an increase in the maximal level $I_{\mathrm{h}}$ activation. Accompanying this shift in the activation curve of $I_{\mathrm{h}}$ was a reduction in the time constant for $I_{\mathrm{h}}$ activation at any given potential by $5-\mathrm{HT}$. We characterized this effect of 5-HT by applying a $10 \mathrm{~s}$ voltage step to fully activate the $I_{\mathrm{h}}$ at $-80 \mathrm{mV}$ and $-90 \mathrm{mV}$, and then comparing the time constant of $I_{\mathrm{h}}$ before and after 5-HT application. The activation time course of $I_{\mathrm{h}}$ was significantly faster after applying 5 -HT at holding potentials of $-80 \mathrm{mV}$ ( $\tau_{\text {fast }}$ control: $695.7 \pm 28.3 \mathrm{~ms}$, 5-HT: $538.8 \pm 55.7 \mathrm{~ms}, p<0.01 ; \tau_{\text {slow }}$ control: $5.7 \pm 0.9 \mathrm{~s}, 5-\mathrm{HT}: 4.2 \pm$ $0.5 \mathrm{~s}, p<0.05$; $n=4$; Fig. $4 D, E)$, or $-90 \mathrm{mV}$ ( $\tau_{\text {fast }}$ control: $544.2 \pm 27.6 \mathrm{~ms}, 5-\mathrm{HT}: 421.6 \pm 58.6 \mathrm{~ms}, p<0.05$; $\tau_{\text {slow }}$ control: $4.4 \pm 0.3 \mathrm{~s}, 5$-HT: $3.0 \pm 0.2 \mathrm{~s}, p<0.01 ; n=4)$. These results indicate that excitation of fusiform cells by 5-HT is accompanied by an acceleration of $\mathrm{HCN}$ channel gating and shift in voltage sensitivity.

Serotonergic regulation of excitability is G-proteindependent and involves cAMP and Src kinase signaling pathways

We next determined what signaling pathways couple 5-HTR to $I_{\mathrm{h}}$. Both $5-\mathrm{HT}_{2 \mathrm{~A} / 2 \mathrm{C}} \mathrm{R}$ and $5-\mathrm{HT}_{7} \mathrm{R}$ are G-protein-coupled receptors (GPCRs). To confirm that G-proteins are required for the 5-HT-induced response, we replaced the GTP in the internal recording solution with $1.5 \mathrm{~mm} \mathrm{GTP}-\gamma-\mathrm{S}$, a nonhydrolysable 
GTP analog that should alter G-proteins signaling and potentially disrupt the ability of $5-\mathrm{HT}_{2 \mathrm{~A} / 2 \mathrm{C}} \mathrm{R}$ and $5-\mathrm{HT}_{7} \mathrm{R}$ to evoke an inward current. Indeed, in the presence of GTP- $\gamma$-S, 5-HT failed to induce an inward current $(-4.8 \pm 4.0 \mathrm{pA}, n=7$; Fig. $5 A, B)$, suggesting that the 5 -HT-evoked current is mediated by a G-proteindependent pathway.

$5-\mathrm{HT}_{2 \mathrm{~A} / 2 \mathrm{C}} \mathrm{R}$ are known to couple to $\mathrm{G}_{\mathrm{q}}$ to activate PLC (phospholipase C), leading to the release of $\mathrm{IP}_{3}$ (inositol1,4,5-trisphosphate) and DAG (diacylglycerol; Hoyer et al., 1994). PLCmediated $\mathrm{IP}_{3}$ might initiate the intracellular $\mathrm{Ca}^{2+}$ release from intracellular endoplasmic reticulum stores, and increase $\mathrm{Ca}^{2+}$ could enhance the $I_{\mathrm{h}}$ (Lüthi and McCormick, 1999). To test this possibility, we determined the effects of intracellular BAPTA on the 5-HT-induced current. When recorded cells were dialyzed with $10 \mathrm{~mm}$ BAPTA, 5-HT still induced a robust inward current $(-53.8 \pm$ $15.0 \mathrm{pA}, p>0.05$, unpaired $t$ test, $n=5$; Fig. $5 A, B)$ compared with the control conditions $(-60.6 \pm 4.1 \mathrm{pA}, n=35)$, suggesting a $\mathrm{Ca}^{2+}$ independent pathway. In addition, PLC-mediated DAG might activate the protein kinase $\mathrm{C}(\mathrm{PKC})$, and $\mathrm{PKC}$ activation could affect the $I_{\mathrm{h}}$ (He et al., 2014). To determine the role of PKC, we included a PKC inhibitor peptide $\mathrm{PKC}_{19-31}$ in the recording pipette and waited $>30$ min after an establishing whole-cell recording, a procedure that effectively blocks PKC activity in other DCN neurons (Bender et al., 2010). However, intracellular dialysis with $10 \mu \mathrm{M} \mathrm{PKC}_{19-31}$ failed to block the 5 -HT-evoked current $(-61.7 \pm 9.9 \mathrm{pA}, p>0.05$, unpaired $t$ test, $n=6$; Fig. $5 A, B)$, compared with the current recorded with normal internal solutions ( $-60.6 \pm 4.1 \mathrm{pA}, n=35)$, suggesting that PLC/PKC signaling pathway is not involved in $5-\mathrm{HT}_{2 \mathrm{~A} / 2 \mathrm{C}} \mathrm{R}$ signaling. Altogether, these data suggest that serotonergic signaling in fusiform cells does not require a PLC-mediated pathway.

$5-\mathrm{HT}_{7} \mathrm{R}$ is known to couple to Gs, and stimulation of Gs leads to activation of adenylyl cyclase and consequently an increase in intracellular cAMP (Hoyer et al., 1994). In addition, it is well known that $I_{\mathrm{h}}$ is often sensitive to intracellular cAMP (Banks et al., 1993; He et al., 2014). Thus, we asked whether intracellular cAMP signaling via activation of $5-\mathrm{HT}_{7} \mathrm{R}$ is involved in the augmentation of $I_{\mathrm{h}}$. To test this possibility, we examined the effects of inhibitors and activators of the cAMP pathway on the 5-HT current. First, we included in the recording pipette an inhibitor of adenylyl cyclase SQ22536 (1 mM). Under these conditions, the 5 -HT current was partially attenuated $(-35.7 \pm 8.4 \mathrm{pA}, p<0.05$, unpaired $t$ test, $n=5$; Fig. $5 A, B)$, compared with control conditions $(-60.6 \pm 4.1 \mathrm{pA}, n=35)$, suggesting a role for adenylyl cyclase. To further investigate whether cAMP is responsible for the effects of 5-HT on the fusiform cells, we examined the effects of a membrane-permeable cAMP analog 8-Br-cAMP, an adenylate cyclase activator, on the 5-HT-evoked current. Bath application of 8-Br-cAMP (0.5-1.0 mM) induced an inward current in most cells recorded, as expected for an activator of $I_{\mathrm{h}}$, and moreover
B ZD7288
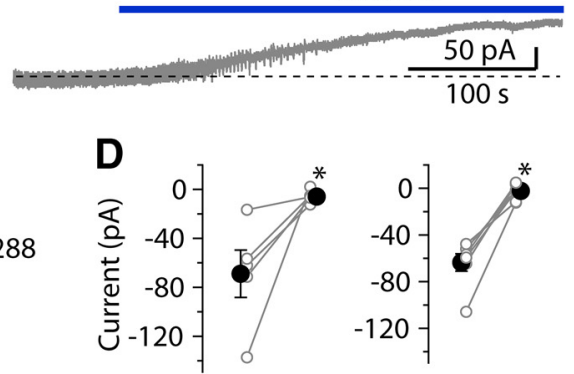

$+\mathrm{CsCl}$ $5-\mathrm{HT} \mathrm{CsCl}$

5-HT ZD
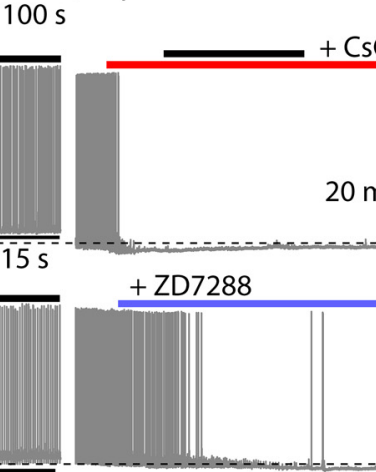

$20 \mathrm{mV} L 2 \mathrm{~min}$
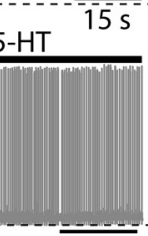

$1 \mathrm{~min}$

$20 \mathrm{mV} 4 \mathrm{~min}$

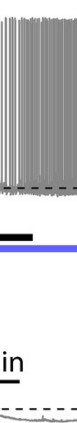

Figure 3. HCN channels are important determinants of intrinsic excitability and the downstream targets of 5-HT-induced and bottom traces, respectively). D. Summary of the effects of $\mathrm{Cs}^{+}(n=5)$ and ZD7288 $(n=7)$ on the 5 -HT evoked current 0 pen clamp, representative spike firing by 5 -HT (right trace). $\boldsymbol{F}$, Similarly, representative traces from another fusiform cell showing that 5 -HT increased the spike firing (left trace), and application of ZD7288 produced a hyperpolarization of membrane potential and also suppressed the increase in the spike firing by $5-\mathrm{HT}$ (right trace). Error bars are \pm SEM.

resulted in a large reduction of the 5-HT-induced current (control: $-59.8 \pm 8.2 \mathrm{pA}, 20 \mathrm{~min}$ after applying 8 -Br-cAMP: $-11.8 \pm$ $6.8 \mathrm{pA} ; p<0.01, n=8$; Fig. $6 A, D)$. These results are consistent with the idea that cAMP signaling pathway is partially involved in the excitatory effects of 5-HT on fusiform cells through activation of $5-\mathrm{HT}_{7} \mathrm{R}$.

Previous studies have shown that Src tyrosine kinase activity is involved in 5- $\mathrm{HT}_{2 \mathrm{~A} / 2 \mathrm{C}} \mathrm{R}$ signaling (González-Maeso et al., 2007; Lu et al., 2008; Schmid and Bohn, 2010; Bigford et al., 2012; Sung et al., 2013), and that Src tyrosine kinase activity could modulate HCN channels (Zong et al., 2005; Arinsburg et al., 2006; Li et al., 2008). To examine the possible contribution of Src tyrosine activity to 5-HT signaling in DCN, we assessed the effects of genistein, PP1, and PP2, selective inhibitors for Src kinase, on the 5 -HT-induced inward current. Bath application of $30 \mu \mathrm{M}$ genistein, a general inhibitor for Src kinase, partially suppressed the 5-HT-evoked current $(74.6 \pm 15.5 \%$ of control; $p<0.05, n=$ $5)$, suggesting that Src tyrosine kinase activity may be involved in the excitatory effects of 5-HT on fusiform cells. Further evidence consistent with this conclusion comes from the effects of PP1 and PP2 on the 5-HT-induced current. Slices were incubated with either PP1 or PP2 (both $20 \mu \mathrm{M}$ ), the selective inhibitors for Src family kinases, before application of 5-HT. Preincubation of PP1 or PP2 for $>1$ h reversibly blocked the inward current evoked by 5-HT (PP1 preincubation: $-12.4 \pm 3.6 \mathrm{pA}, 1 \mathrm{~h}$ after wash of PP1: $-43.0 \pm 3.7 \mathrm{pA} ; p<0.05, n=7$; PP2 preincubation: $-15.8 \pm 3.6$ $\mathrm{pA}, 1 \mathrm{~h}$ after wash of PP2: $-38.9 \pm 9.7 \mathrm{pA} ; p<0.05, n=6$; Fig. $6 B-C, E-F)$. Together, these data suggest that serotonergic regu- 
A
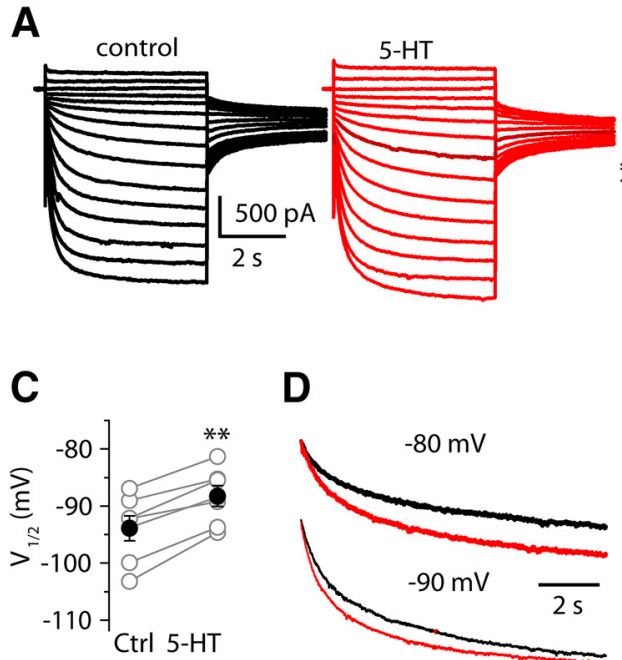

D

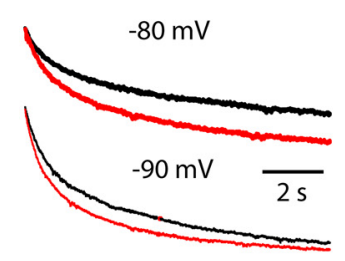

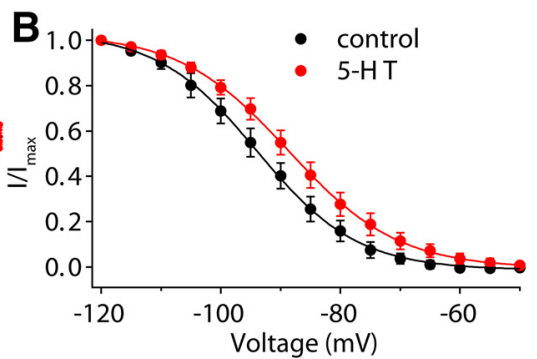

E

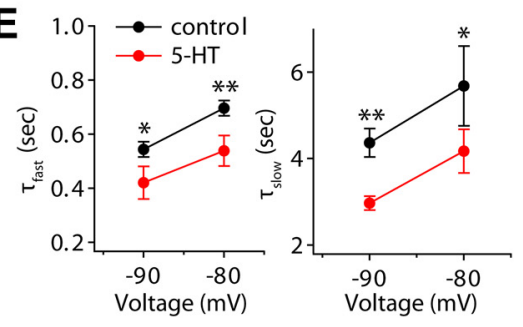

Figure 4. 5-HT positively shifts the activation curve for the $I_{\mathrm{h}}$ and reduces the time constant for $I_{\mathrm{h}}$ activation. $A$, Sample current traces from a fusiform cell before and after applying 5 -HT. Currents were evoked with a series of $5 \mathrm{~s}$ voltage steps from -120 to $-50 \mathrm{mV}$, in $5 \mathrm{mV}$ increments, from a holding potential of $-60 \mathrm{mV}$, and followed by a test pulse to $-75 \mathrm{mV}$. B, Mean normalized tail currents are plotted as a function of voltage steps and fit with the Boltzmann equation $(n=7)$. Tail currents were measured at $-75 \mathrm{mV}$ in the presence of $\mathrm{Ba}^{2+}$ to eliminate the contamination of $\mathrm{K}_{\mathrm{ir}}$ C, Pooled data showing the effects of 5-HT on $\mathrm{V}_{1 / 2}$. Open symbols represent $V_{1 / 2}$ of individual neurons, and filled symbols represent the mean of $V_{1 / 2}$. D , Superimposition of current traces evoked by $10 \mathrm{~s}$ steps to -80 and $-90 \mathrm{mV}$ from a holding potential of $-60 \mathrm{mV}$ before and after applying 5 -HT. E, Pooled data of time constants for $I_{\mathrm{h}}$ activation in the absence and presence of $5-\mathrm{HT}(n=4)$ at two voltages. Error bars are \pm SEM.
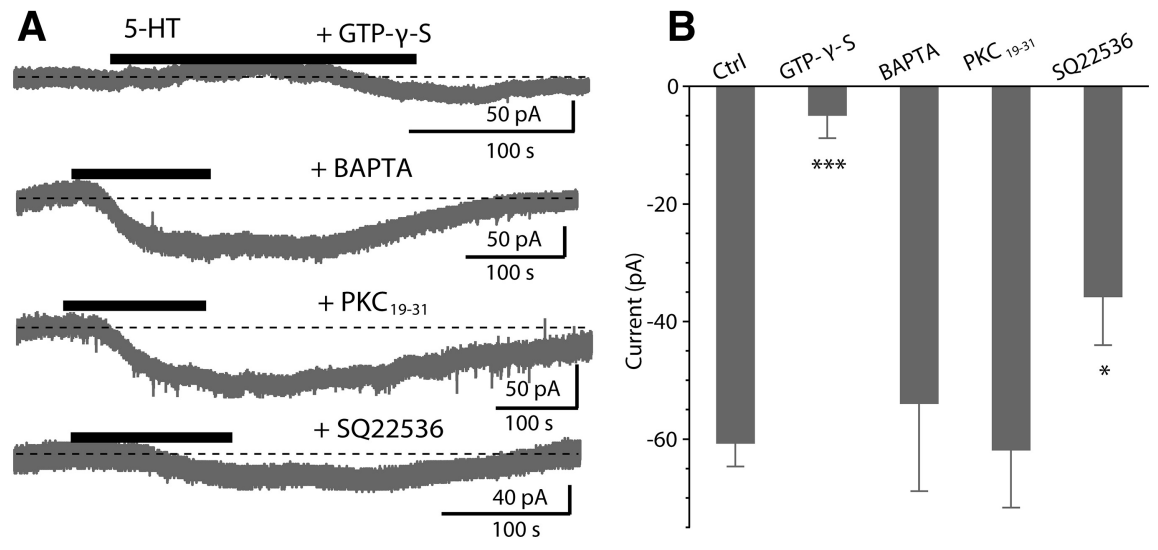

Figure 5. A G-protein-dependent transduction mechanism. $\boldsymbol{A}$, Thirty minutes after establishing the whole-cell configuration, application of $10 \mu \mathrm{m} 5$-HT evoked a response with intracellular perfusions of $1.5 \mathrm{~mm} \mathrm{GTP}-\gamma-\mathrm{S}, 10 \mathrm{~mm}$ BAPTA, $10 \mu \mathrm{M}$ PKC $_{19-31}$ and $1 \mathrm{~mm}$ SQ22536. $\boldsymbol{B}$, Pooled data for the 5-HT-evoked current under normal internal recording solution $(n=35)$ or during intracellular dialysis of GTP- $\gamma-\mathrm{S}(n=7)$, BAPTA $(n=5)$, PKC $_{19-31}(n=6)$, and SQ22536 $(n=5)$. Bars represent mean \pm SEM; ${ }^{*} p<$ $0.05,{ }^{* *} p<0.01,{ }^{* * *} p<0.001$ (unpaired $t$ test).

lation of neuronal excitability of fusiform cells is G-proteindependent, and involves cAMP and Src signaling-dependent pathways through activation of $5-\mathrm{HT}_{7} \mathrm{R}$ and $5-\mathrm{HT}_{2 \mathrm{~A} / 2 \mathrm{C}} \mathrm{R}$, thereby enhancing resting activation of $I_{\mathrm{h}}$.

\section{Stimulation of serotonergic afferents regulates excitability of fusiform cells}

While the data so far demonstrate that exogenous 5-HT enhances the excitability of DCN neurons, it is important to ask whether endogenous transmitter released from serotonergic afferent fibers has actions similar to that of exogenous 5-HT. To test this, we took advantage of a Tph2-ChR2-YFP mouse line in which the light activated cation channel ChR2 is expressed selectively in serotonergic neurons (Zhao et al., 2011). We first confirmed that ChR2-EYFP-positive fibers were present in the DCN by labeling

sectioned material with a fluorescent antibody which recognizes EYFP (Zhao et al., 2011; see Materials and Methods). Fibers were abundantly present in the cell body and deep layers of the DCN, but nearly absent from the molecular layer (Fig. $7 A, B$ ). A similar pattern of serotonergic innervation of the DCN observed in the Mexican free-tailed bat, labeled fibers are much higher density in fusiform cell layer than in the molecular layer (Hurley and Thompson, 2001). In contrast, fibers are densely concentrated in the molecular layer but less heavily in the fusiform cell layer in rat, cat, guinea pig, and opossum (Willard et al., 1984; Klepper and Herbert, 1991; Thompson et al., 1995; Thompson and Thompson, 2001), suggesting species differences in fiber distribution. Interestingly, label was also absent in the cerebellar molecular layer but apparent in the granule cell region (Fig. $7 A$ ), which is consistent with the observations in some species (Dieudonné, 2001). We next examined whether optical simulation of serotonergic axonal terminals in brain slices could produce a response in voltage-clamped fusiform cells. Photostimulation with a single $5 \mathrm{~ms}$ blue light pulse did not induce detectable responses; however, tetanic photostimulation (20, 50 , or $100 \mathrm{~Hz}, 5 \mathrm{~ms}$ light pulses for $10-20$ s) resulted in a slow inward current in a significant fraction of fusiform cells tested (33.3\%, 18 of 54 cells; $10 \mu \mathrm{M}$ fluoxetine was added into ACSF solutions to decrease rate of 5-HT clearance in some experiments). This result is consistent with the observation that the $5-\mathrm{HT}$ release by activation of ChR2 depends on the duration of light exposure and light frequency (Dankoski and Wightman, 2013; Dugué et al., 2014; Miyazaki et al., 2014). This inward current was markedly reduced by $10 \mu \mathrm{M}$ ketanserin (light stimulus: $-30.1 \pm 5.3 \mathrm{pA}$, ketanserin: $-4.5 \pm 3.6$ pA; $p<0.05, n=4$; Fig. $8 A, B)$, suggesting that the light-evoked slow responses were mediated by serotonergic transmission. These data also suggest that serotonergic transmission is intrinsically slow, consistent with a idea that 5 -HT mostly acts via a volume transmission mode in the CNS (Bunin and Wightman, 1998; Ridet and Privat, 2000; Dieudonné, 2001). Consistent with this idea, nonjunctional varicosities have been observed in the DCN (Thompson et al., 1995). More importantly, in some cases, using current-clamp recording, tetanic photostimulation depolarized the cells sufficient to trigger or increases spontaneous spike firing (Fig. 8C). To further explore the effect of serotonergic axon stimulation on the excitability of fusiform cells, action potentials were elicited by injecting a series of current steps $(-10$ to $+50 \mathrm{pA}, 500-1000 \mathrm{~ms}$, $\Delta I=20 \mathrm{pA}$ ) before and after light stimulus. Photostimulation increased the firing rate upon 10 or $30 \mathrm{pA}$ depolarizing steps in five of eight cells tested (10 pA baseline: $3.2 \pm 1.0 \mathrm{~Hz}$, light stim- 

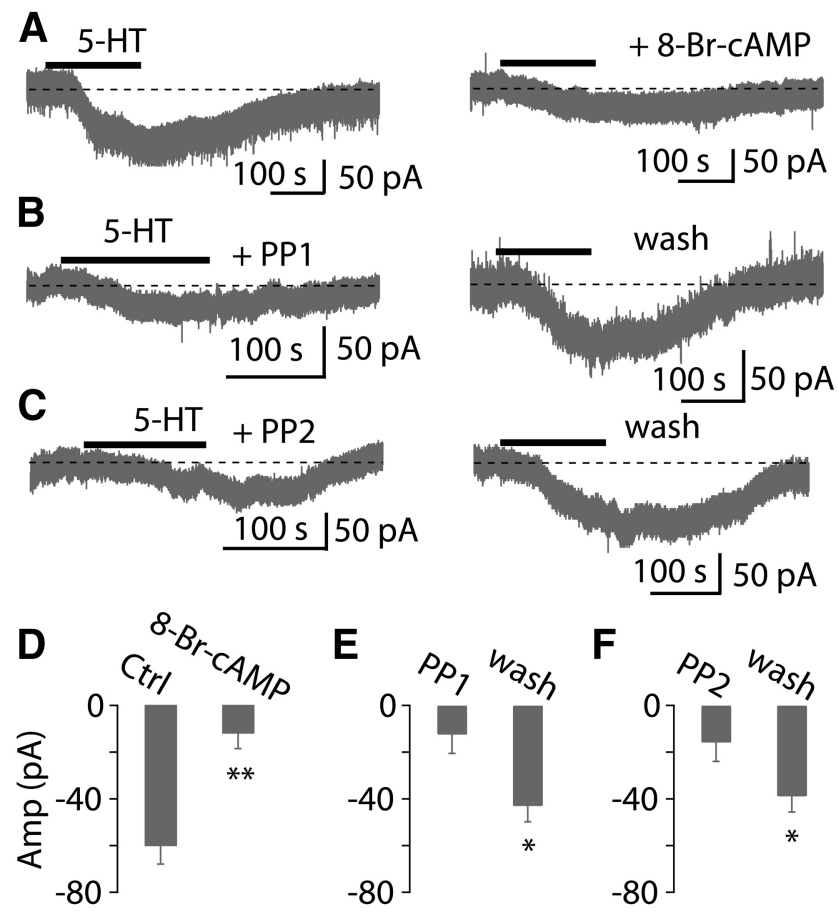

Figure 6. CAMP and Src kinase activities are involved in the serotonergic signaling. $A$, Left, Application of $10 \mu \mathrm{m} 5-\mathrm{HT}$ induced an inward current. Right, Twenty minute bath application of $1 \mathrm{~mm}$ 8-Br-cAMP, a membrane-permeable cAMP analog, largely blocked this inward current. $\boldsymbol{B}$, C, Left, Preincubation of PP1 or PP2, selective Src kinase inhibitors, for $>1 \mathrm{~h}$, application of 10 $\mu \mathrm{M} 5-\mathrm{HT}$ induced a small inward current. Right, After $1 \mathrm{~h}$ washout of PP1 and PP2 $(20 \mu \mathrm{M})$, application of 5-HT induced a larger inward current. D-F, Pooled data showing the 5-HTevoked current in the presence and absence of $8-\operatorname{Br}-\operatorname{cAMP}(n=8), \operatorname{PP} 1(n=7)$, and PP2 ( $n=$ 6). Bars are mean \pm SEM

ulus: $5.9 \pm 1.0 \mathrm{~Hz}$; $30 \mathrm{pA}$ baseline: $9.6 \pm 1.7 \mathrm{~Hz}$, light stimulus: $14.2 \pm 2.5 \mathrm{~Hz} ; p<0.05, n=5$; Fig. $8 D, E)$. Thus, these data suggest that 5 -HT is released from serotonergic fibers by optical stimulation in the DCN and can regulate the excitability of fusiform cells in a manner similar to that of exogenous 5-HT.

\section{Discussion}

\section{Serotonergic regulation of fusiform} cells

The DCN is composed of multiple cell types distributed in different sensory processing domains (Oertel and Young, 2004); knowing which cells are affected by $5-\mathrm{HT}$, and how, may allow the functional role of 5-HT to emerge. Serotonergic fibers densely innervate the cell layer that contains fusiform somata, and the molecular and deep layers that contain the dendrites of fusiform cells (Klepper and Herbert, 1991; Thompson et al., 1995; Hurley and Thompson, 2001; Thompson and Thompson, 2001). We found that after blocking fast synaptic inputs (glutamate, GABA, and glycine), exogenous or endogenous 5-HT depolarized fusiform cells and increased spontaneous spike rate, indicating a direct action on fusiform cell excitability. Therefore, fusiform principal cells in the DCN are a target of serotonergic raphe fibers. Although 5-HT regulates the excitability of fusiform cells by altering their intrinsic properties, it remains to be seen whether 5 -HT also modulates synaptic function. Fusiform cells receive excitatory inputs from parallel fibers, auditory nerve and possibly T-stellate cells in the ventral cochlear nucleus (VCN; Oertel et al., 2011). Given that serotonergic fibers also strongly innervate the granule cell domain and VCN (Klepper and Herbert, 1991; Thompson et al., 1995; Thompson and Thompson, 2001), and
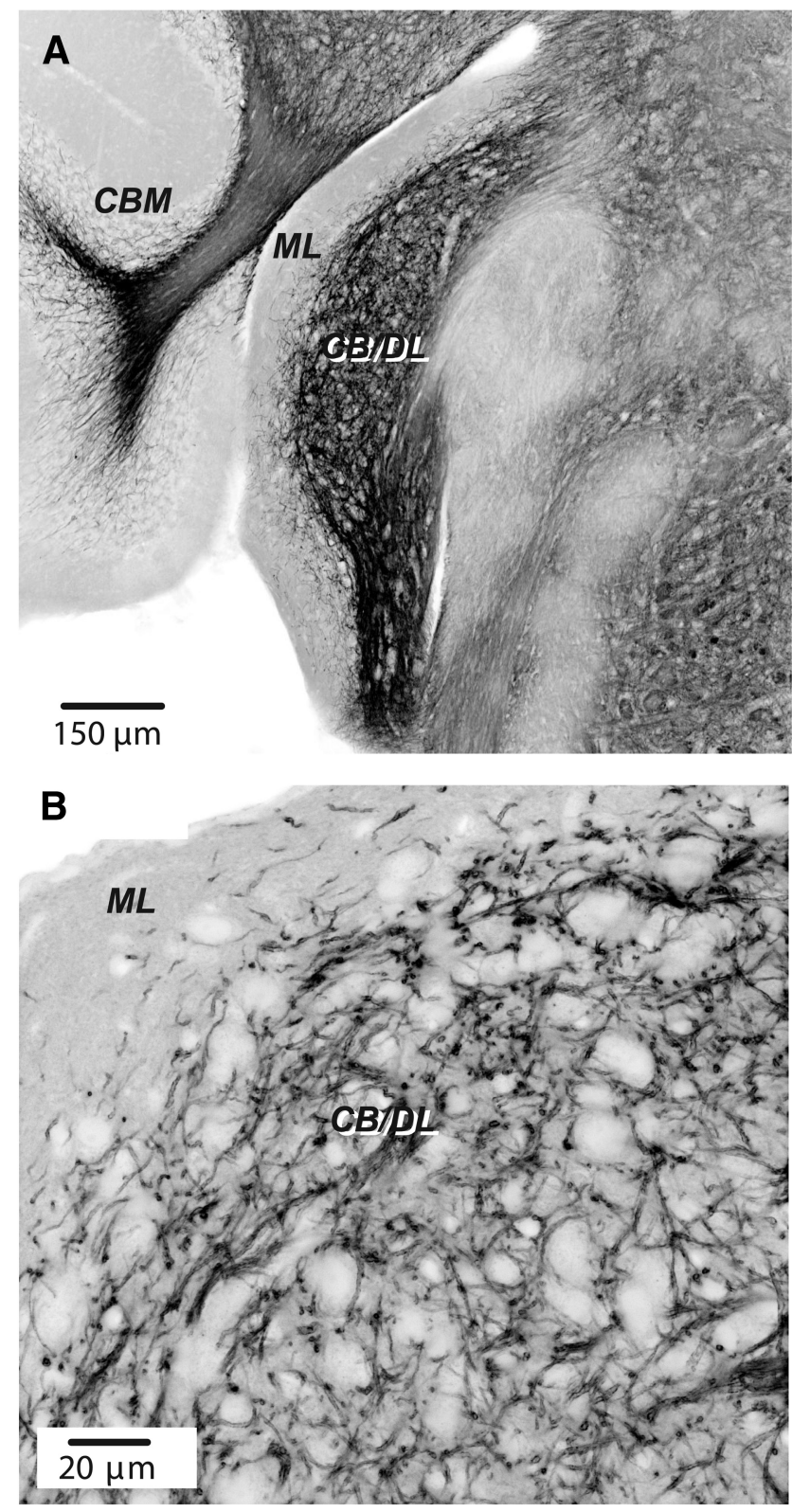

Figure 7. Expression of ChR2 in DCN in a Tph2-ChR2-EYFP mouse line. $\boldsymbol{A}$, Section showing $D C N$ and adjoining structures. Image printed in negative shows fluorescent labeling using antibody labeling for EYFP. ML, Molecular layer of DCN; CB/DL, fusiform cell body and deep layers; CBM, cerebellar cortex. Confocal image taken with a $10 \times$ objective. $\boldsymbol{B}$, Labeling in DCN imaged using a $60 \times$ oil-immersion objective. Confocal image stack of four planes. Note preponderance of labeling up to the cell body layer and relative absence in the molecular layer.

that T-stellate cells are sensitive to 5-HT (Oertel et al., 2011), 5-HT may also modulate excitatory inputs to fusiform cells. Strong labeling for serotonergic fibers is observed in the DCN region containing inhibitory vertical cells. As serotonergic inputs could potentially contact vertical cells, it will be important to investigate whether 5-HT regulates the activity of vertical cells and their feedforward inhibition to fusiform cells.

Our data indicate that $5-\mathrm{HT}_{2 \mathrm{~A} / 2 \mathrm{C}} \mathrm{R}$ and $5-\mathrm{HT}_{7} \mathrm{R}$ mediate the effects of 5-HT on fusiform cells. The 5-HT response was partially blocked by the selective $5-\mathrm{HT}_{2 \mathrm{~A}} \mathrm{R}$ antagonist MDL-11939, slightly suppressed by $5-\mathrm{HT}_{2 \mathrm{C}} \mathrm{R}$ antagonist SB-242084, and partially mimicked by the $5-\mathrm{HT}_{2} \mathrm{R}$ agonist $\alpha$-methyl-5-HT, indicating that the 5-HT response was partially mediated by some 


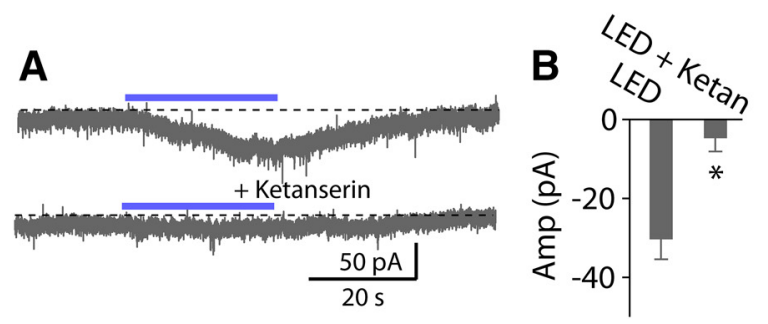

C
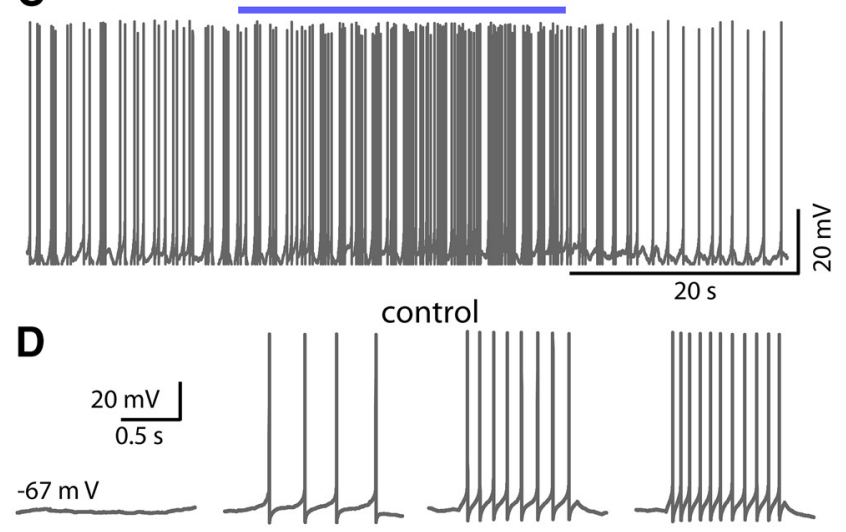

light stimulus
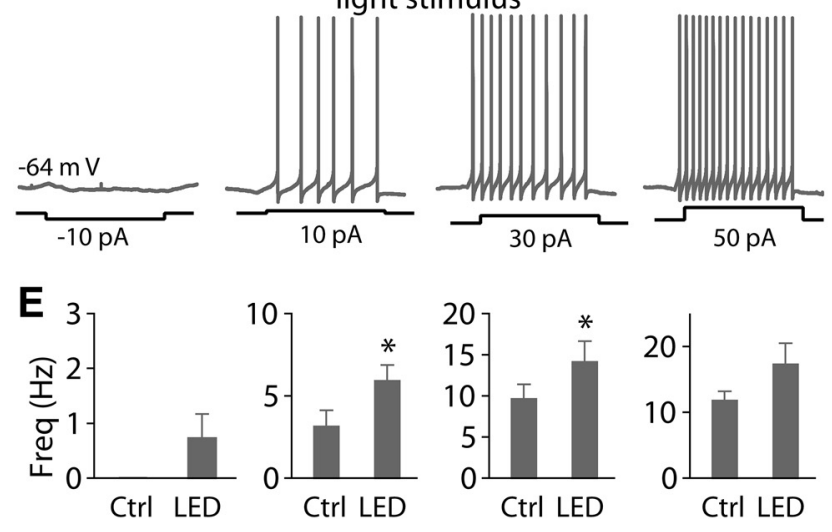

Figure 8. Photostimulation of serotonergic axons expressing ChR2 increases spike firing in fusiform cells. $A$, Sustained photostimulation (blue light pulse with $5 \mathrm{~ms}$ duration) elicited an inward current. Top trace, An inward current evoked by a 30 s train of light pulses at $100 \mathrm{~Hz}$. Bottom trace, This current was blocked by $10 \mu \mathrm{m}$ ketanserin. $\boldsymbol{B}$, Pooled data show photostimulation-evoked currents were largely blocked by ketanserin $(n=4)$ ). C, Example traces from a fusiform cell show that tetanic photostimulation increases the firing rate. $\boldsymbol{D}$, Representative traces of action potential firing elicited by somatic injection of current pulses $(-10,10,30$, and $50 \mathrm{pA}, 1 \mathrm{~s}$ duration) illustrating the effects of photostimulation of serotonergic fibers. $\boldsymbol{E}$, Pooled data show photostimulation of serotonergic fibers significantly increase the firing rate at 10 or $30 \mathrm{pA}$ depolarizing steps $(n=5)$.

combination of $5-\mathrm{HT}_{2 \mathrm{~A} / 2 \mathrm{C}} \mathrm{R}$. Although ketanserin at high concentration $(10 \mu \mathrm{M})$ almost completely blocked the response, it may also block $5-\mathrm{HT}_{7} \mathrm{R}$ (Adham et al., 1998), suggesting that $5-\mathrm{HT}_{7} \mathrm{R}$ may contribute to the 5 - $\mathrm{HT}$ response. Indeed, the 5 -HT-response was partially blocked by the $5-\mathrm{HT}_{7} \mathrm{R}$ antagonist SB-269970, and the remaining currents was suppressed by MDL11939. In addition, our data show that 8-Br-cAMP partially mimicked and occluded the 5-HT-evoked response, consistent with studies showing that $5-\mathrm{HT}_{7} \mathrm{R}$ depolarizes neurons through activation of adenylyl cyclase and increase in cAMP (Hoyer et al., 1994). All these data suggest that the effects of 5-HT on fusiform cells are mediated probably by coactivation of $5-\mathrm{HT}_{2 \mathrm{~A} / 2 \mathrm{C}} \mathrm{R}$ and $5-\mathrm{HT}_{7} \mathrm{R}$ in individual neurons. In support, $5-\mathrm{HT}_{2 \mathrm{~A}} \mathrm{R}$ and $5-\mathrm{HT}_{2 \mathrm{C}} \mathrm{R}$ are present in the DCN (Pazos et al., 1985; Thompson et al., 1994; Wright et al., 1995; Cornea-Hébert et al., 1999), and labeling of large, presumptive fusiform cells is apparent in DCN of Htr7-EGFP mice (www.gensat.org). Similar coexpression of $5-\mathrm{HT}_{2 \mathrm{~A}} \mathrm{R}$ and $5-\mathrm{HT}_{7} \mathrm{R}$ in individual cells has been observed in other central neurons (Béique et al., 2004; Bonsi et al., 2007).

\section{Ionic mechanism and signal transduction pathways}

Despite the multiplicity of receptors involved in the 5-HT response, HCN channels are likely to be entirely responsible for the resulting enhancement of fusiform cell excitability. Our data show that $I_{\mathrm{h}}$ is involved in setting resting potential and ongoing spontaneous firing. Pharmacological block of $I_{\mathrm{h}}$ with $\mathrm{Cs}^{+}$or ZD7288 was sufficient to abolish the 5-HT response. 5-HT shifts positively the activation curve for $I_{\mathrm{h}}$ without altering maximal activation, thus activating more channels when the cell is at rest. Finally, 5-HT decreased activation time constants for $I_{\mathrm{h}}$. Because $I_{\mathrm{h}}$ time constants increase with depolarization (Chen et al., 2001), a uniform decrease in time constants implies a rightward shift in the activation curve. Together, $I_{\mathrm{h}}$ is the primary downstream target of 5-HT in fusiform cells, as seen in several other regions of the CNS (Bobker and Williams, 1989; Pape and McCormick, 1989; Takahashi and Berger, 1990; Larkman and Kelly, 1992; Cardenas et al., 1999).

The actions of 5-HT were G-protein-dependent, probably engaging cAMP and Src kinase signaling pathways. 5-HT responses were abolished by GTP- $\gamma$-S, which arrests G-protein function. Furthermore, the adenylyl cyclase inhibitor SQ22536 partially blocked the 5-HT response. 8-Br-cAMP evoked an inward current and occluded the 5-HT response. Moreover, 5-HT's effects on $I_{\mathrm{h}}$ channel gating mirrored the effects of cAMP on these channels (Chen et al., 2001). Accordingly, we speculate that 5- $\mathrm{HT}_{7} \mathrm{R}$ could stimulate adenylate cyclase to upregulate intracellular cAMP. Increased cAMP may act directly on HCN, although an additional route involving phosphorylation cannot be excluded here. Intracellular dialysis of BAPTA or $\mathrm{PKC}_{19-31}$ did not affect the 5-HT current, excluding PLC/ $/ \mathrm{IP}_{3} / \mathrm{Ca}^{2+}$ and PLC/PKC signaling involvement. Genistein, a tyrosine kinase inhibitor, partially blocked the 5-HT response, and preincubation of the Src kinase inhibitors PP1 or PP2 inhibited the 5-HT response. Thus, activation of $5-\mathrm{HT}_{2 \mathrm{~A} / 2 \mathrm{C}} \mathrm{R}$ may also lead to increased Src kinase activity, and thereby enhance the $I_{\mathrm{h}}$. Notably, Src kinase signaling pathways have been shown to modulate $I_{\mathrm{h}}$ in a manner similar to 5-HT and cAMP (Li et al., 2008; He et al., 2014). All these data suggest that serotonergic signaling in fusiform cells may be mediated by both multiple receptors and multiple signaling pathways.

\section{Functional implications}

Given the importance of the DCN in auditory function and tinnitus pathophysiology, the serotonergic regulation of neuronal excitability of the primary output neurons may have important outcomes.

Activation of the serotonergic raphe-DCN pathway could increase excitability and reduce acoustic thresholds of fusiform cells. It may be that this pathway functions as a "gain-setter" in controlling DCN output. Serotonergic neurons in the raphe nuclei fire at 3-5 Hz in quiet, awake animals (Trulson and Jacobs, 1979; Trulson and Trulson, 1982a; Rasmussen et al., 1986). In addition, the raphe-DCN pathway may be regulated by sensory inputs and behavioral state (Trulson and Trulson, 1982b). The serotonergic system receives direct input from inferior colliculus (Pollak Dorocic et al., 2014), and acoustic stimuli activate the serotonergic system (Trulson and Trulson, 1982b; Cransac et al., 
1998), suggesting that acoustic stimuli might regulate the serotonergic raphe-DCN pathway. Increased activity of serotonergic neurons is associated with behavioral arousal. Thus, 5-HT release in response to sensory stimuli or behavioral events might dynamically regulate the excitability and acoustic threshold of fusiform neurons by modulating their membrane properties.

Aberrant serotonergic transmission at one or more levels in central auditory pathways might play a role in the pathogenesis of tinnitus. Although the mechanisms underlying tinnitus remain unclear, spontaneous hyperactivity in DCN fusiform cells is associated with tinnitus (Kaltenbach et al., 2005; Kaltenbach and Godfrey, 2008; Baizer et al., 2012). Our data show that 5-HT increases excitability of fusiform cells, and may lead to enhanced downstream excitation, consistent with previous in vivo studies suggesting that $5-\mathrm{HT}_{2} \mathrm{R}$ and $5-\mathrm{HT}_{7} \mathrm{R}$ play a role in the regulation of auditory network excitability (Bourson et al., 1997; Brennan et al., 1997; Applegate and Tecott, 1998; Holmes et al., 1998; Oliveira and Zatz, 1999). Thus, serotonergic dysfunction (e.g., upregulation of 5-HT levels, 5-HTR density or receptor sensitivity to $5-\mathrm{HT}$ ) in DCN might contribute to the generation and maintenance of tinnitus (Marriage and Barnes, 1995; Simpson and Davies, 2000; Caperton and Thompson, 2010; Hurley and Hall, 2011; Baizer et al., 2012). Accordingly, upregulation of extracellular 5-HT levels in DCN increases with noise exposure (Cransac et al., 1998), which can cause tinnitus (Kaltenbach, 2011). Notably, in spinal cord, 5-HT2R density and sensitivity to 5-HT can be upregulated following spinal injury (Murray et al., 2010; Husch et al., 2012). It remains to be investigated whether such modification of serotonergic activity could be induced following cochlear damage. Moreover, SSRIs are commonly used to treat tinnitus in patients with and without depression (Parnes, 1997; Andersson and McKenna, 1998; Folmer and Shi, 2004; Robinson et al., 2007; Fornaro and Martino, 2010; Baldo et al., 2012); however, the success of such treatments are inconsistent, and some patients reported a worsening of tinnitus. Acute treatment of SSRIs should increase extracellular concentrations of 5-HT, which based on our study, may then activate $5-\mathrm{HT}_{2 \mathrm{~A}} /{ }_{2 \mathrm{C}} \mathrm{R}$ and $5-\mathrm{HT}_{7} \mathrm{R}$ and enhance DCN output. Responses to pharmaceutical agents may change as transmitter and receptor levels accommodate to the treatment. Thus, activation of 5-HT receptors in fusiform cells may be associated with the onset of a therapeutic response, indeed some patients report tinnitus after beginning SSRIs regiment (Robinson, 2007; Robinson et al., 2007). Perhaps therapeutic action of SSRIs on tinnitus results from secondary plasticity in 5-HT signaling (e.g., downregulation of 5-HT receptor) induced by boosting serotonergic activity after chronic SSRIs treatment. Indeed, it is well established that a decrease in $5-\mathrm{HT}_{2 \mathrm{~A} / 2 \mathrm{C}} \mathrm{R}$ density can be produced by chronic administration of 5-HT and other 5-HT receptor agonists (Buckholtz et al., 1988; Eison et al., 1989; Anji et al., 2000), as well as antidepressants (Eison and Mullins, 1996). Thus, a long-term reduction in $5-\mathrm{HT}_{2} \mathrm{R}$ density by chronic treatment with SSRIs might play a role in the therapeutic effects of SSRIs in tinnitus. The current study showing the action of 5 -HT at a cellular level in the DCN may provide a basis for future studies exploring how SSRIs affect tinnitus.

\section{References}

Adham N, Zgombick JM, Bard J, Branchek TA (1998) Functional characterization of the recombinant human 5-hydroxytryptamine7(a) receptor isoform coupled to adenylate cyclase stimulation. J Pharmacol Exp Ther 287:508-514. Medline

Andersson G, McKenna L (1998) Tinnitus masking and depression. Audiology 37:174-182. CrossRef Medline

Anji A, Kumari M, Sullivan Hanley NR, Bryan GL, Hensler JG (2000) Reg- ulation of 5-HT(2A) receptor mRNA levels and binding sites in rat frontal cortex by the agonist DOI and the antagonist mianserin. Neuropharmacology 39:1996-2005. CrossRef Medline

Apostolides PF, Trussell LO (2013) Rapid, activity-independent turnover of vesicular transmitter content at a mixed glycine/GABA synapse. J Neurosci 33:4768-4781. CrossRef Medline

Apostolides PF, Trussell LO (2014) Control of interneuron firing by subthreshold synaptic potentials in principal cells of the dorsal cochlear nucleus. Neuron 83:324-330. CrossRef Medline

Applegate CD, Tecott LH (1998) Global increases in seizure susceptibility in mice lacking 5-HT2C receptors: a behavioral analysis. Exp Neurol 154: 522-530. CrossRef Medline

Araneda R, Andrade R (1991) 5-Hydroxytryptamine2 and 5-hydroxytryptamine $1 \mathrm{~A}$ receptors mediate opposing responses on membrane excitability in rat association cortex. Neuroscience 40:399-412. CrossRef Medline

Arinsburg SS, Cohen IS, Yu HG (2006) Constitutively active Src tyrosine kinase changes gating of $\mathrm{HCN} 4$ channels through direct binding to the channel proteins. J Cardiovasc Pharmacol 47:578-586. CrossRef Medline

Baizer JS, Manohar S, Paolone NA, Weinstock N, Salvi RJ (2012) Understanding tinnitus: the dorsal cochlear nucleus, organization and plasticity. Brain Res 1485:40-53. CrossRef Medline

Baldo P, Doree C, Molin P, McFerran D, Cecco S (2012) Antidepressants for patients with tinnitus. Cochrane Database Syst Rev 9:CD003853. CrossRef Medline

Banks MI, Pearce RA, Smith PH (1993) Hyperpolarization-activated cation current (Ih) in neurons of the medial nucleus of the trapezoid body: voltage-clamp analysis and enhancement by norepinephrine and cAMP suggest a modulatory mechanism in the auditory brain stem. J Neurophysiol 70:1420-1432. Medline

Béique JC, Campbell B, Perring P, Hamblin MW, Walker P, Mladenovic L, Andrade R (2004) Serotonergic regulation of membrane potential in developing rat prefrontal cortex: coordinated expression of 5-hydroxytryptamine (5-HT)1A, 5-HT2A, and 5-HT7 receptors. J Neurosci 24: 4807-4817. CrossRef Medline

Bender KJ, Ford CP, Trussell LO (2010) Dopaminergic modulation of axon initial segment calcium channels regulates action potential initiation. Neuron 68:500-511. CrossRef Medline

Bigford GE, Chaudhry NS, Keane RW, Holohean AM (2012) 5-Hydroxytryptamine $5 \mathrm{HT} 2 \mathrm{C}$ receptors form a protein complex with $N$-methyl-D-aspartate GluN2A subunits and activate phosphorylation of Src protein to modulate motoneuronal depolarization. J Biol Chem 287:11049-11059. CrossRef Medline

Bobker DH, Williams JT (1989) Serotonin augments the cationic current Ih in central neurons. Neuron 2:1535-1540. CrossRef Medline

Bonsi P, Cuomo D, Ding J, Sciamanna G, Ulrich S, Tscherter A, Bernardi G, Surmeier DJ, Pisani A (2007) Endogenous serotonin excites striatal cholinergic interneurons via the activation of 5-HT 2C, 5- HT6, and 5-HT7 serotonin receptors: implications for extrapyramidal side effects of serotonin reuptake inhibitors. Neuropsychopharmacology 32:1840-1854. CrossRef Medline

Bourson A, Kapps V, Zwingelstein C, Rudler A, Boess FG, Sleight AJ (1997) Correlation between 5-HT7 receptor affinity and protection against sound-induced seizures in DBA/2J mice. Naunyn Schmiedebergs Arch Pharmacol 356:820-826. CrossRef Medline

Brennan TJ, Seeley WW, Kilgard M, Schreiner CE, Tecott LH (1997) Sound-induced seizures in serotonin 5-HT2c receptor mutant mice. Nat Genet 16:387-390. CrossRef Medline

Brozoski TJ, Bauer CA, Caspary DM (2002) Elevated fusiform cell activity in the dorsal cochlear nucleus of chinchillas with psychophysical evidence of tinnitus. J Neurosci 22:2383-2390. Medline

Brozoski TJ, Wisner KW, Sybert LT, Bauer CA (2012) Bilateral dorsal cochlear nucleus lesions prevent acoustic-trauma induced tinnitus in an animal model. J Assoc Res Otolaryngol 13:55-66. CrossRef Medline

Buckholtz NS, Zhou DF, Freedman DX (1988) Serotonin2 agonist administration down-regulates rat brain serotonin2 receptors. Life Sci 42:24392445. CrossRef Medline

Bunin MA, Wightman RM (1998) Quantitative evaluation of 5-hydroxytryptamine (serotonin) neuronal release and uptake: an investigation of extrasynaptic transmission. J Neurosci 18:4854-4860. Medline

Caperton KK, Thompson AM (2010) Activation of serotonergic neurons during salicylate-induced tinnitus. Laryngoscope 120:S203. CrossRef Medline

Cardenas CG, Mar LP, Vysokanov AV, Arnold PB, Cardenas LM, Surmeier 
DJ, Scroggs RS (1999) Serotonergic modulation of hyperpolarizationactivated current in acutely isolated rat dorsal root ganglion neurons. J Physiol 518:507-523. CrossRef Medline

Chapin EM, Andrade R (2001a) A 5-HT(7) receptor-mediated depolarization in the anterodorsal thalamus: I. Pharmacological characterization. J Pharmacol Exp Ther 297:395-402. Medline

Chapin EM, Andrade R (2001b) A 5-HT(7) receptor-mediated depolarization in the anterodorsal thalamus: II. Involvement of the hyperpolarization-activated current I(h). J Pharmacol Exp Ther 297:403-409. Medline

Chen S, Wang J, Siegelbaum SA (2001) Properties of hyperpolarizationactivated pacemaker current defined by coassembly of HCN1 and HCN2 subunits and basal modulation by cyclic nucleotide. J Gen Physiol 117: 491-504. CrossRef Medline

Cornea-Hébert V, Riad M, Wu C, Singh SK, Descarries L (1999) Cellular and subcellular distribution of the serotonin 5-HT2A receptor in the central nervous system of adult rat. J Comp Neurol 409:187-209. CrossRef Medline

Cransac H, Cottet-Emard JM, Pequignot JM, Peyrin L (1995) Monoamines (noradrenaline, dopamine, serotonin) in the rat cochlear nuclei: endogenous levels and turnover. Hear Res 90:65-71. CrossRef Medline

Cransac H, Cottet-Emard JM, Hellström S, Peyrin L (1998) Specific soundinduced noradrenergic and serotonergic activation in central auditory structures. Hear Res 118:151-156. CrossRef Medline

Dahlström A, Fuxe K (1964) Localization of monoamines in the lower brain stem. Experientia 20:398-399. CrossRef Medline

Dankoski EC, Wightman RM (2013) Monitoring serotonin signaling on a subsecond time scale. Front Integr Neurosci 7:44. CrossRef Medline

Dehmel S, Pradhan S, Koehler S, Bledsoe S, Shore S (2012) Noise overexposure alters long-term somatosensory-auditory processing in the dorsal cochlear nucleus-possible basis for tinnitus-related hyperactivity? J Neurosci 32:1660-1671. CrossRef Medline

Descarries L, Watkins KC, Garcia S, Beaudet A (1982) The serotonin neurons in nucleus raphe dorsalis of adult rat: a light and electron microscope radioautographic study. J Comp Neurol 207:239-254. CrossRef Medline

Dieudonné S (2001) Serotonergic neuromodulation in the cerebellar cortex: cellular, synaptic, and molecular basis. Neuroscientist 7:207-219. CrossRef Medline

Dugué GP, Lörincz ML, Lottem E, Audero E, Matias S, Correia PA, Léna C, Mainen ZF (2014) Optogenetic recruitment of dorsal raphe serotonergic neurons acutely decreases mechanosensory responsivity in behaving mice. PloS One 9:e105941. CrossRef Medline

Ebert U, Ostwald J (1992) Serotonin modulates auditory information processing in the cochlear nucleus of the rat. Neurosci Lett 145:51-54. CrossRef Medline

Eison AS, Mullins UL (1996) Regulation of central 5-HT2A receptors: a review of in vivo studies. Behav Brain Res 73:177-181. Medline

Eison AS, Eison MS, Yocca FD, Gianutsos G (1989) Effects of imipramine and serotonin-2 agonists and antagonists on serotonin-2 and betaadrenergic receptors following noradrenergic or serotonergic denervation. Life Sci 44:1419-1427. CrossRef Medline

Folmer RL, Shi YB (2004) SSRI use by tinnitus patients: interactions between depression and tinnitus severity. Ear Nose Throat J 83:107-108, 110, 112. Medline

Fornaro M, Martino M (2010) Tinnitus psychopharmacology: a comprehensive review of its pathomechanisms and management. Neuropsychiatr Dis Treat 6:209-218. Medline

Golding NL, Oertel D (1997) Physiological identification of the targets of cartwheel cells in the dorsal cochlear nucleus. J Neurophysiol 78:248-260. Medline

González-Maeso J, Weisstaub NV, Zhou M, Chan P, Ivic L, Ang R, Lira A, Bradley-Moore M, Ge Y, Zhou Q, Sealfon SC, Gingrich JA (2007) Hallucinogens recruit specific cortical 5-HT(2A) receptor-mediated signaling pathways to affect behavior. Neuron 53:439-452. CrossRef Medline

Harasztosi C, Forsythe ID, Szûcs G, Stanfield PR, Rusznák Z (1999) Possible modulatory role of voltage-activated $\mathrm{Ca}(2+)$ currents determining the membrane properties of isolated pyramidal neurones of the rat dorsal cochlear nucleus. Brain Res 839:109-119. CrossRef Medline

He C, Chen F, Li B, Hu Z (2014) Neurophysiology of HCN channels: from cellular functions to multiple regulations. Prog Neurobiol 112:1-23. CrossRef Medline

Hirsch JA, Oertel D (1988) Intrinsic properties of neurones in the dorsal cochlear nucleus of mice, in vitro. J Physiol 396:535-548. CrossRef Medline

Holmes C, Arranz MJ, Powell JF, Collier DA, Lovestone S (1998) 5-HT2A and 5-HT2C receptor polymorphisms and psychopathology in late onset Alzheimer's disease. Hum Mol Genet 7:1507-1509. CrossRef Medline

Hoyer D, Clarke DE, Fozard JR, Hartig PR, Martin GR, Mylecharane EJ, Saxena PR, Humphrey PP (1994) International union of pharmacology classification of receptors for 5-hydroxytryptamine (serotonin). Pharmacol Rev 46:157-203. Medline

Huot P, Fox SH, Brotchie JM (2011) The serotonergic system in Parkinson's disease. Prog Neurobiol 95:163-212. CrossRef Medline

Hurley LM, Hall IC (2011) Context-dependent modulation of auditory processing by serotonin. Hear Res 279:74-84. CrossRef Medline

Hurley LM, Pollak GD (1999) Serotonin differentially modulates responses to tones and frequency-modulated sweeps in the inferior colliculus. J Neurosci 19:8071-8082. Medline

Hurley LM, Pollak GD (2005) Serotonin modulates responses to speciesspecific vocalizations in the inferior colliculus. J Comp Physiol A Neuroethol Sens Neural Behav Physiol 191:535-546. CrossRef Medline

Hurley LM, Thompson AM (2001) Serotonergic innervation of the auditory brainstem of the Mexican free-tailed bat, Tadarida brasiliensis. J Comp Neurol 435:78-88. CrossRef Medline

Husch A, Van Patten GN, Hong DN, Scaperotti MM, Cramer N, HarrisWarrick RM (2012) Spinal cord injury induces serotonin supersensitivity without increasing intrinsic excitability of mouse V2a interneurons. J Neurosci 32:13145-13154. CrossRef Medline

Imig TJ, Bibikov NG, Poirier P, Samson FK (2000) Directionality derived from pinna-cue spectral notches in cat dorsal cochlear nucleus. J Neurophysiol 83:907-925. Medline

Jasper JR, Kosaka A, To ZP, Chang DJ, Eglen RM (1997) Cloning, expression and pharmacology of a truncated splice variant of the human 5-HT7 receptor (h5-HT7b). Br J Pharmacol 122:126-132. CrossRef Medline

Jones BJ, Blackburn TP (2002) The medical benefit of 5-HT research. Pharmacol Biochem Behav 71:555-568. CrossRef Medline

Kaltenbach JA (2011) Tinnitus: models and mechanisms. Hear Res 276:52-60. CrossRef Medline

Kaltenbach JA, Godfrey DA (2008) Dorsal cochlear nucleus hyperactivity and tinnitus: are they related? Am J Audiol 17:S148-S161. CrossRef Medline

Kaltenbach JA, Zacharek MA, Zhang J, Frederick S (2004) Activity in the dorsal cochlear nucleus of hamsters previously tested for tinnitus following intense tone exposure. Neurosci Lett 355:121-125. CrossRef Medline

Kaltenbach JA, Zhang J, Finlayson P (2005) Tinnitus as a plastic phenomenon and its possible neural underpinnings in the dorsal cochlear nucleus. Hear Res 206:200-226. CrossRef Medline

Kanold PO, Manis PB (1999) Transient potassium currents regulate the discharge patterns of dorsal cochlear nucleus pyramidal cells. J Neurosci 19:2195-2208. Medline

Klepper A, Herbert H (1991) Distribution and origin of noradrenergic and serotonergic fibers in the cochlear nucleus and inferior colliculus of the rat. Brain Res 557:190-201. CrossRef Medline

Koehler SD, Shore SE (2013) Stimulus timing-dependent plasticity in dorsal cochlear nucleus is altered in tinnitus. J Neurosci 33:19647-19656. CrossRef Medline

Larkman PM, Kelly JS (1992) Ionic mechanisms mediating 5-hydroxytryptamine- and noradrenaline-evoked depolarization of adult rat facial motoneurones. J Physiol 456:473-490. CrossRef Medline

Leao RM, Li S, Doiron B, Tzounopoulos T (2012) Diverse levels of an inwardly rectifying potassium conductance generate heterogeneous neuronal behavior in a population of dorsal cochlear nucleus pyramidal neurons. J Neurophysiol 107:3008-3019. CrossRef Medline

Levine RA (1999) Somatic (craniocervical) tinnitus and the dorsal cochlear nucleus hypothesis. Am J Otolaryngol 20:351-362. CrossRef Medline

Li CH, Zhang Q, Teng B, Mustafa SJ, Huang JY, Yu HG (2008) Src tyrosine kinase alters gating of hyperpolarization-activated $\mathrm{HCN} 4$ pacemaker channel through Tyr531. Am J Physiol Cell Physiol 294:C355-C362. CrossRef Medline

Li S, Choi V, Tzounopoulos T (2013) Pathogenic plasticity of Kv7.2/3 channel activity is essential for the induction of tinnitus. Proc Natl Acad Sci U S A 110:9980-9985. CrossRef Medline 
Lu R, Alioua A, Kumar Y, Kundu P, Eghbali M, Weisstaub NV, Gingrich JA, Stefani E, Toro L (2008) c-Src tyrosine kinase, a critical component for 5-HT2A receptor-mediated contraction in rat aorta. J Physiol 586:38553869. CrossRef Medline

Lucki I (1998) The spectrum of behaviors influenced by serotonin. Biol Psychiatry 44:151-162. CrossRef Medline

Luo H, Pace E, Zhang X, Zhang J (2014) Blast-induced tinnitus and spontaneous firing changes in the rat dorsal cochlear nucleus. J Neurosci Res 92:1466-1477. CrossRef Medline

Lüthi A, McCormick DA (1999) Modulation of a pacemaker current through $\mathrm{Ca}(2+)$-induced stimulation of cAMP production. Nat Neurosci 2:634-641. CrossRef Medline

Manis PB, Spirou GA, Wright DD, Paydar S, Ryugo DK (1994) Physiology and morphology of complex spiking neurons in the guinea pig dorsal cochlear nucleus. J Comp Neurol 348:261-276. CrossRef Medline

Marriage J, Barnes NM (1995) Is central hyperacusis a symptom of 5-hydroxytryptamine (5-HT) dysfunction? J Laryngol Otol 109:915-921. Medline

May BJ (2000) Role of the dorsal cochlear nucleus in the sound localization behavior of cats. Hear Res 148:74-87. CrossRef Medline

Meltzer CC, Smith G, DeKosky ST, Pollock BG, Mathis CA, Moore RY, Kupfer DJ, Reynolds CF 3rd (1998) Serotonin in aging, late-life depression, and Alzheimer's disease: the emerging role of functional imaging. Neuropsychopharmacology 18:407-430. CrossRef Medline

Middleton JW, Kiritani T, Pedersen C, Turner JG, Shepherd GM, Tzounopoulos T (2011) Mice with behavioral evidence of tinnitus exhibit dorsal cochlear nucleus hyperactivity because of decreased GABAergic inhibition. Proc Natl Acad Sci U S A 108:7601-7606. CrossRef Medline

Miyazaki KW, Miyazaki K, Tanaka KF, Yamanaka A, Takahashi A, Tabuchi S, Doya K (2014) Optogenetic activation of dorsal raphe serotonin neurons enhances patience for future rewards. Curr Biol 24:2033-2040. CrossRef Medline

Molitor SC, Manis PB (2003) Dendritic Ca2 + transients evoked by action potentials in rat dorsal cochlear nucleus pyramidal and cartwheel neurons. J Neurophysiol 89:2225-2237. Medline

Murray KC, Nakae A, Stephens MJ, Rank M, D’Amico J, Harvey PJ, Li X, Harris RL, Ballou EW, Anelli R, Heckman CJ, Mashimo T, Vavrek R, Sanelli L, Gorassini MA, Bennett DJ, Fouad K (2010) Recovery of motoneuron and locomotor function after spinal cord injury depends on constitutive activity in 5-HT2C receptors. Nat Med 16:694-700. CrossRef Medline

Oertel D, Young ED (2004) What's a cerebellar circuit doing in the auditory system? Trends Neurosci 27:104-110. CrossRef Medline

Oertel D, Wright S, Cao XJ, Ferragamo M, Bal R (2011) The multiple functions of T stellate/multipolar/chopper cells in the ventral cochlear nucleus. Hear Res 276:61-69. CrossRef Medline

Oishi N, Kanzaki S, Shinden S, Saito H, Inoue Y, Ogawa K (2010) Effects of selective serotonin reuptake inhibitor on treating tinnitus in patients stratified for presence of depression or anxiety. Audiol Neurootol 15:187193. CrossRef Medline

Oliveira JR, Zatz M (1999) The study of genetic polymorphisms related to serotonin in Alzheimer's disease: a new perspective in a heterogenic disorder. Braz J Med Biol Res 32:463-467. CrossRef Medline

Pál B, Pór A, Szucs G, Kovács I, Rusznák Z (2003) HCN channels contribute to the intrinsic activity of cochlear pyramidal cells. Cell Mol Life Sci 60: 2189-2199. CrossRef Medline

Pape HC, McCormick DA (1989) Noradrenaline and serotonin selectively modulate thalamic burst firing by enhancing a hyperpolarizationactivated cation current. Nature 340:715-718. CrossRef Medline

Parent A, Descarries L, Beaudet A (1981) Organization of ascending serotonin systems in the adult rat brain: a radioautographic study after intraventricular administration of $\left[{ }^{3} \mathrm{H}\right] 5$-hydroxytryptamine. Neuroscience 6:115-138. CrossRef Medline

Parnes SM (1997) Current concepts in the clinical management of patients with tinnitus. Eur Arch Otorhinolaryngol 254:406-409. CrossRef Medline

Pazos A, Cortés R, Palacios JM (1985) Quantitative autoradiographic mapping of serotonin receptors in the rat brain: II. Serotonin-2 receptors. Brain Res 346:231-249. CrossRef Medline

Perrier JF, Cotel F (2008) Serotonin differentially modulates the intrinsic properties of spinal motoneurons from the adult turtle. J Physiol 586: 1233-1238. CrossRef Medline

Pierce PA, Peroutka SJ (1990) Antagonist properties of d-LSD at 5-hydroxytryptamine2 receptors. Neuropsychopharmacology 3:503-508. Medline

Pollak Dorocic I, Fürth D, Xuan Y, Johansson Y, Pozzi L, Silberberg G, Carlén M, Meletis K (2014) A whole-brain atlas of inputs to serotonergic neurons of the dorsal and median raphe nuclei. Neuron 83:663-678. CrossRef Medline

Rasmussen K, Strecker RE, Jacobs BL (1986) Single unit response of noradrenergic, serotonergic and dopaminergic neurons in freely moving cats to simple sensory stimuli. Brain Res 369:336-340. CrossRef Medline

Revelis J, Thompson AM, Britton BH, Thompson GC (1998) Effects of para-chlorophenylalanine ( $\mathrm{pCPA}$ ) on the bush baby auditory brainstem response. Hear Res 116:119-130. CrossRef Medline

Ridet I, Privat A (2000) Volume transmission. Trends Neurosci 23:58-59. CrossRef Medline

Robinson S (2007) Antidepressants for treatment of tinnitus. Prog Brain Res 166:263-271. CrossRef Medline

Robinson SK, Viirre ES, Stein MB (2007) Antidepressant therapy in tinnitus. Hear Res 226:221-231. CrossRef Medline

Salvinelli F, Casale M, Paparo F, Persico AM, Zini C (2003) Subjective tinnitus, temporomandibular joint dysfunction, and serotonin modulation of neural plasticity: causal or casual triad? Med Hypotheses 61:446-448. CrossRef Medline

Schmid CL, Bohn LM (2010) Serotonin, but not $N$-methyltryptamines, activates the serotonin $2 \mathrm{~A}$ receptor via a $\beta$-arrestin $2 / \mathrm{Src} / \mathrm{Akt}$ signaling complex in vivo. J Neurosci 30:13513-13524. CrossRef Medline

Shemen L (1998) Fluoxetine for treatment of tinnitus. Otolaryngol Head Neck Surg 118:421. CrossRef

Shen Y, Monsma FJ Jr, Metcalf MA, Jose PA, Hamblin MW, Sibley DR (1993) Molecular cloning and expression of a 5-hydroxytryptamine7 serotonin receptor subtype. J Biol Chem 268:18200-18204. Medline

Simpson JJ, Davies WE (2000) A review of evidence in support of a role for 5-HT in the perception of tinnitus. Hear Res 145:1-7. CrossRef Medline

Stark P, Fuller RW, Wong DT (1985) The pharmacologic profile of fluoxetine. J Clin Psychiatry 46:7-13. Medline

Steinbusch HW (1981) Distribution of serotonin-immunoreactivity in the central nervous system of the rat-cell bodies and terminals. Neuroscience 6:557-618. CrossRef Medline

Sung DJ, Noh HJ, Kim JG, Park SW, Kim B, Cho H, Bae YM (2013) Serotonin contracts the rat mesenteric artery by inhibiting 4-aminopyridinesensitive KV channels via the 5-HT2A receptor and Src tyrosine kinase. Exp Mol Med 45:e67. CrossRef Medline

Sutherland DP, Glendenning KK, Masterton RB (1998) Role of acoustic striae in hearing: discrimination of sound-source elevation. Hear Res 120: 86-108. CrossRef Medline

Takahashi T, Berger AJ (1990) Direct excitation of rat spinal motoneurones by serotonin. J Physiol 423:63-76. CrossRef Medline

Tanaka E, North RA (1993) Actions of 5-hydroxytryptamine on neurons of the rat cingulate cortex. J Neurophysiol 69:1749-1757. Medline

Thompson AM, Thompson GC (2001) Serotonin projection patterns to the cochlear nucleus. Brain Res 907:195-207. CrossRef Medline

Thompson AM, Wiechmann AF (2002) 5-HT(1A) receptor subtype mRNA expression in cochlear nucleus. Hear Res 164:77-81. CrossRef Medline

Thompson GC, Thompson AM, Garrett KM, Britton BH (1994) Serotonin and serotonin receptors in the central auditory system. Otolaryngol Head Neck Surg 110:93-102. CrossRef Medline

Thompson AM, Moore KR, Thompson GC (1995) Distribution and origin of serotoninergic afferents to guinea pig cochlear nucleus. J Comp Neurol 351:104-116. CrossRef Medline

Trulson ME, Jacobs BL (1979) Raphe unit activity in freely moving cats: correlation with level of behavioral arousal. Brain Res 163:135-150. CrossRef Medline

Trulson ME, Trulson VM (1982a) Activity of nucleus raphe pallidus neurons across the sleep-waking cycle in freely moving cats. Brain Res 237: 232-237. CrossRef Medline

Trulson ME, Trulson VM (1982b) Differential effects of phasic auditory and visual stimuli on serotonergic neurons in the nucleus raphe dorsalis and 
nucleus raphe pallidus in freely moving cats. Neurosci Lett 32:137-142. CrossRef Medline

Tzounopoulos T, Kim Y, Oertel D, Trussell LO (2004) Cell-specific, spike timing-dependent plasticities in the dorsal cochlear nucleus. Nat Neurosci 7:719-725. CrossRef Medline

Wang H, Brozoski TJ, Turner JG, Ling L, Parrish JL, Hughes LF, Caspary DM (2009) Plasticity at glycinergic synapses in dorsal cochlear nucleus of rats with behavioral evidence of tinnitus. Neuroscience 164:747-759. CrossRef Medline

Willard FH, Ho RH, Martin GF (1984) The neuronal types and the distribution of 5-hydroxytryptamine and enkephalin-like immunoreactive fibers in the dorsal cochlear nucleus of the North American opossum. Brain Res Bull 12:253-266. CrossRef Medline

Wong DT, Bymaster FP, Engleman EA (1995) Prozac (fluoxetine, Lilly 110140), the first selective serotonin uptake inhibitor and an antidepressant drug: twenty years since its first publication. Life Sci 57:411-441. CrossRef Medline

Wood WE, Roseberry TK, Perkel DJ (2013) HTR2 receptors in a songbird premotor cortical-like area modulate spectral characteristics of zebra finch song. J Neurosci 33:2908-2915. CrossRef Medline
Wright DE, Seroogy KB, Lundgren KH, Davis BM, Jennes L (1995) Comparative localization of serotonin $1 \mathrm{~A}, 1 \mathrm{C}$, and 2 receptor subtype mRNAs in rat brain. J Comp Neurol 351:357-373. CrossRef Medline

Zhang S, Oertel D (1994) Neuronal circuits associated with the output of the dorsal cochlear nucleus through fusiform cells. J Neurophysiol 71:914930. Medline

Zhang ZW (2003) Serotonin induces tonic firing in layer V pyramidal neurons of rat prefrontal cortex during postnatal development. J Neurosci 23:3373-3384. Medline

Zhao S, Ting JT, Atallah HE, Qiu L, Tan J, Gloss B, Augustine GJ, Deisseroth K, Luo M, Graybiel AM, Feng G (2011) Cell type-specific channelrhodopsin-2 transgenic mice for optogenetic dissection of neural circuitry function. Nat Methods 8:745-752. CrossRef Medline

Zong X, Eckert C, Yuan H, Wahl-Schott C, Abicht H, Fang L, Li R, Mistrik P, Gerstner A, Much B, Baumann L, Michalakis S, Zeng R, Chen Z, Biel M (2005) A novel mechanism of modulation of hyperpolarizationactivated cyclic nucleotide-gated channels by Src kinase. J Biol Chem 280:34224-34232. CrossRef Medline 